\title{
Review
}

\section{Subgroup-Specific Diagnostic, Prognostic, and Predictive Markers Influencing Pediatric Medulloblastoma Treatment}

\author{
Sutapa Ray ${ }^{1,2}$, Nagendra K. Chaturvedi ${ }^{1,2}$, Kishor K. Bhakat ${ }^{2,3}$, Angie Rizzino ${ }^{2,4}$ \\ and Sidharth Mahapatra $1,2,5, *$ (D)
}

1 Department of Pediatrics, University of Nebraska Medical Center, 601 S Saddle Creek Road, Omaha, NE 68198, USA; sutapa.ray@unmc.edu (S.R.); nchaturvedi@unmc.edu (N.K.C.)

2 Fred and Pamela Buffet Cancer Center, University of Nebraska Medical Center, Omaha, NE 68105, USA; kishor.bhakat@unmc.edu (K.K.B.); arizzino@unmc.edu (A.R.)

3 Department of Genetics, Cell Biology, and Anatomy, University of Nebraska Medical Center, Omaha, NE 68198, USA

4 Eppley Institute for Research in Cancer and Allied Disease, University of Nebraska Medical Center, Omaha, NE 68198, USA

5 Department of Biochemistry and Molecular Biology, University of Nebraska Medical Center, Omaha, NE 68198, USA

* Correspondence: sidharth.mahapatra@unmc.edu; Tel.: +1-(402)-599-7754

check for updates

Citation: Ray, S.; Chaturvedi, N.K.; Bhakat, K.K.; Rizzino, A.; Mahapatra, S. Subgroup-Specific Diagnostic, Prognostic, and Predictive Markers Influencing Pediatric Medulloblastoma Treatment. Diagnostics 2022, 12, 61 . https://doi.org/10.3390/diagnostics 12010061

Academic Editors: Ewa Bien and Janina Baranowska-Kortylewicz

Received: 15 November 2021

Accepted: 18 December 2021

Published: 28 December 2021

Publisher's Note: MDPI stays neutral with regard to jurisdictional claims in published maps and institutional affiliations.

Copyright: (C) 2021 by the authors. Licensee MDPI, Basel, Switzerland. This article is an open access article distributed under the terms and conditions of the Creative Commons Attribution (CC BY) license (https:// creativecommons.org/licenses/by/ $4.0 /)$.

\begin{abstract}
Medulloblastoma (MB) is the most common malignant central nervous system tumor in pediatric patients. Mainstay of therapy remains surgical resection followed by craniospinal radiation and chemotherapy, although limitations to this therapy are applied in the youngest patients. Clinically, tumors are divided into average and high-risk status on the basis of age, metastasis at diagnosis, and extent of surgical resection. However, technological advances in high-throughput screening have facilitated the analysis of large transcriptomic datasets that have been used to generate the current classification system, dividing patients into four primary subgroups, i.e., WNT (wingless), SHH (sonic hedgehog), and the non-SHH/WNT subgroups 3 and 4. Each subgroup can further be subdivided on the basis of a combination of cytogenetic and epigenetic events, some in distinct signaling pathways, that activate specific phenotypes impacting patient prognosis. Here, we delve deeper into the genetic basis for each subgroup by reviewing the extent of cytogenetic events in key genes that trigger neoplastic transformation or that exhibit oncogenic properties. Each of these discussions is further centered on how these genetic aberrations can be exploited to generate novel targeted therapeutics for each subgroup along with a discussion on challenges that are currently faced in generating said therapies. Our future hope is that through better understanding of subgroup-specific cytogenetic events, the field may improve diagnosis, prognosis, and treatment to improve overall quality of life for these patients.
\end{abstract}

Keywords: medulloblastoma; WNT; SHH; group 3; group 4

\section{Introduction}

Medulloblastoma (MB), a primitive neuroectodermal tumor (PNET), is concurrently the most common malignant pediatric brain tumor and the leading cause of cancer-related childhood mortality [1-5]. Annual incidence for pediatric medulloblastoma in the United States is approximately 500 cases [1,6,7]. Accounting for $40 \%$ of tumors arising in the posterior fossa, these tumors can grow rapidly and invade important structures, triggering cerebellar dysfunction and disrupting cerebrospinal fluid circulation (Figure 1). Clinical presentation and symptomatology can reflect this pattern of growth. Children often present with difficulties in coordination and gait (cerebellar signs) and/or with early morning headaches, nausea, vomiting, papilledema, and double vision (hydrocephalus); average time from onset of symptoms to diagnosis can be as short as $2-3$ months $[8,9]$. 


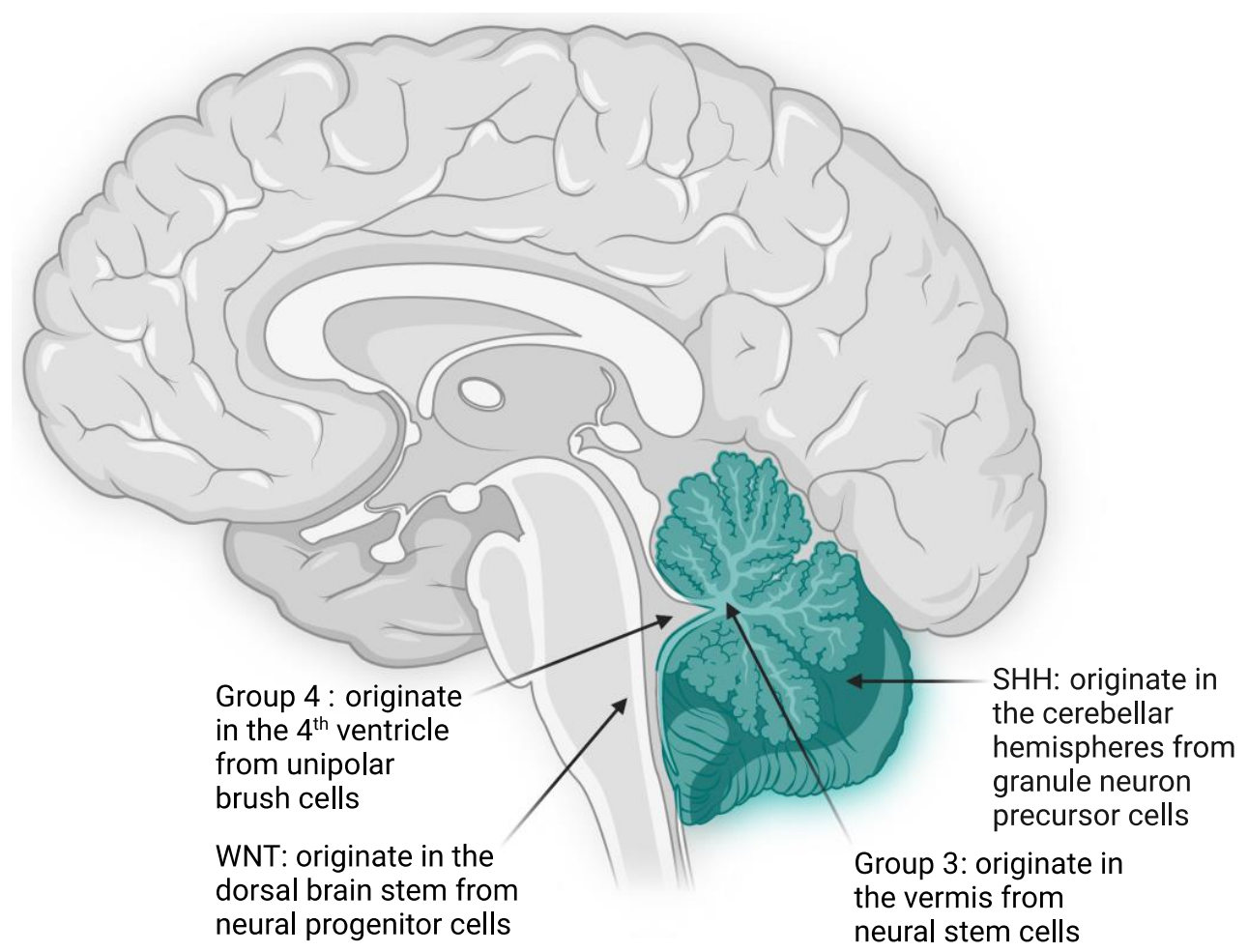

Figure 1. Origin of medulloblastoma tumors. Schematic showing the subgroup-specific origination and precursor cell for medulloblastoma tumors. Cerebellum is depicted in teal color. WNT, wingless subgroup; $\mathrm{SHH}$, sonic hedgehog subgroup.

Genome-wide high-throughput analyses of large cohorts of medulloblastoma patients have revealed four distinct molecular subgroups, each possessing unique genetic and epigenetic alterations [10-20]. Medulloblastomas are now subdivided into wingless (WNT), sonic hedgehog $(\mathrm{SHH})$, group 3, and group 4 tumors, with each subgroup possessing a distinct transcriptomic and methylation profiles, somatic genetic aberrations, demographic distributions, histologies, and clinical outcomes (Figure 2) [7,21]. However, these primary subgroups can be further subdivided into at least 12 subtypes on the basis of clustering of unique molecular and clinical features influencing overall risk and survivability (Table 1) [22].

Table 1. Tumor subtypes within medulloblastoma subgroups *

\begin{tabular}{|c|c|c|c|c|c|c|}
\hline Subgroup & Subtype & Frequency & $\begin{array}{c}\text { Median } \\
\text { Age (yrs) }\end{array}$ & $\begin{array}{l}\text { Distinguishing } \\
\text { Genetic Events }\end{array}$ & $\begin{array}{l}\text { Metastasis } \\
\text { Incidence }\end{array}$ & $\begin{array}{c}\text { 5-Year } \\
\text { Overall } \\
\text { Survival }\end{array}$ \\
\hline \multirow{2}{*}{ WNT } & WNT $\alpha$ & $70 \%$ & 10 & $>95 \%$ monosomy chromosome 6 & $9 \%$ & $97 \%$ \\
\hline & WNT $\beta$ & $30 \%$ & 20 & $\sim 30 \%$ monosomy chromosome 6 & $21 \%$ & $100 \%$ \\
\hline \multirow{4}{*}{ SHH } & $\mathrm{SHH} \alpha$ & $29 \%$ & 8 & $\begin{array}{c}\text { Loss of 9q, 10q, 17p; gain of 9p; enriched in MYCN, GLI2 amp } \\
\text { and TP53 mutations (35\%) }\end{array}$ & $20 \%$ & $70 \%$ ** \\
\hline & $\mathrm{SHH} \beta$ & $16 \%$ & 1.9 & Significant gain in chromosome 2 ; focal PTEN deletions $(25 \%)$ & $33 \%$ & $67 \%$ \\
\hline & $\mathrm{SHH} \gamma$ & $21 \%$ & 1.3 & Low copy number alterations & $9 \%$ & $88 \%$ \\
\hline & SHHठ & $34 \%$ & 26 & Enriched in TERT mutations (90\%) & $9 \%$ & $89 \%$ \\
\hline \multirow{3}{*}{ Group 3} & $\operatorname{Grp} 3 \alpha$ & $46 \%$ & 4.8 & \multirow{3}{*}{$\begin{array}{c}\mathrm{i17q} ; \text { loss of } 8 \mathrm{q} \text { and } 17 \mathrm{p} \\
\text { OTX2 gain and DDX31 loss; activation of GFI1 and GFI1B } \\
\text { oncogenes } \\
\mathrm{i17q} ; 8 \mathrm{q} \text { gain and } M Y C \text { amp }\end{array}$} & $43 \%$ & $66 \%$ \\
\hline & Grp $3 \beta$ & $26 \%$ & 7.6 & & $20 \%$ & $56 \%$ \\
\hline & $\operatorname{Grp} 3 \gamma$ & $28 \%$ & 5 & & $39 \%$ & $42 \%$ \\
\hline \multirow{3}{*}{ Group 4} & $\operatorname{Grp} 4 \alpha$ & $30 \%$ & 8.2 & i17q; loss of $8 \mathrm{p} ; 7 \mathrm{q}$ gain; $M Y C N$ and $C D K 6$ amp & $40 \%$ & $67 \%$ \\
\hline & Grp $4 \beta$ & $33 \%$ & 10 & i17q; $17 \mathrm{p}$ loss; SNCAIP dup & $41 \%$ & $75 \%$ \\
\hline & Grp $4 \gamma$ & $37 \%$ & 7 & i17q; loss of $8 \mathrm{p} ; 7 \mathrm{q}$ gain; $C D K 6$ amp & $39 \%$ & $83 \%$ \\
\hline
\end{tabular}

* Data compiled from Cavalli et al., Cancer Cell 2017, 31: 737-754 [22]. ${ }^{* *}$ Five-year OS for SHH $\alpha$ decreases to $\sim 30 \%$ with TP53 mutations. GFI1/1B, growth factor-independent; GLI2, effector of hedgehog signaling; i17q, isochromosome 17q; MYC, cytoplasmic MYC proto-oncogene; MYCN, nuclear MYC proto-oncogene; PTEN, phosphatase and tensin homolog; SNCAIP, synuclein alpha-interacting protein; TERT, telomerase. 


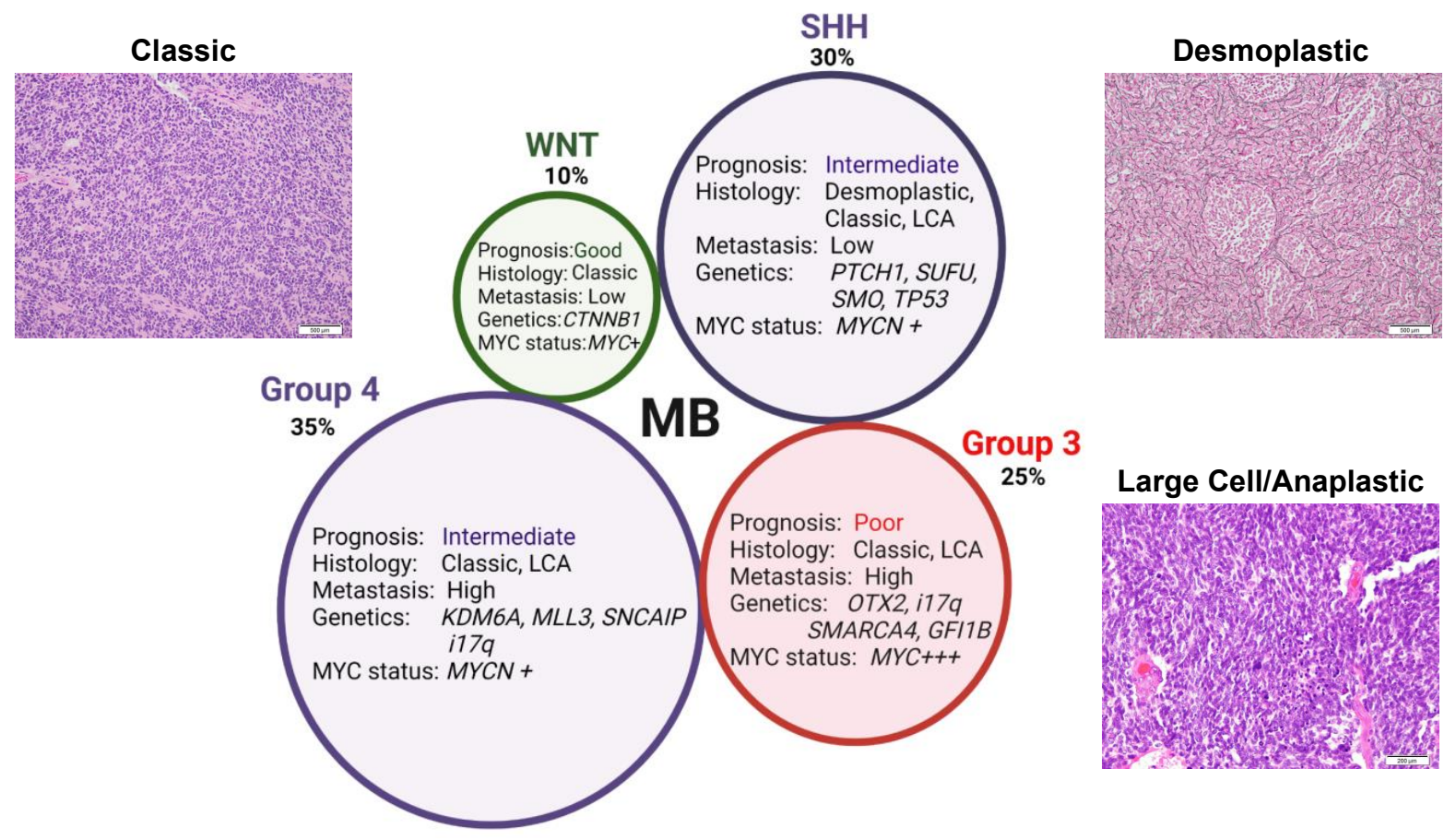

Figure 2. Medulloblastoma subgroup features and characteristics. Schematic depicting the four primary medulloblastoma subgroups and their unique features. Regarding histology, classic tumors are characterized by sheets of small, round, monomorphic cells possessing high nuclear-to-cytoplasmic ratios and hyperchromatic nuclei. Desmoplastic tumors are characterized by nodules of tumor cells displaying neurocytic differentiation within pale islands. Large cell/anaplastic tumors feature cells with nuclear enlargement, hyperchromatism, a high mitotic index, and atypical mitotic figures. Hematoxylin and eosin staining, 200-500X magnification. (Images courtesy of Deborah Perry, Children's Hospital \& Medical Center, NE). CTNNB1, catenin beta 1; GFI1B, growth factor 1B transcriptional repressor; i17q, isochromosome 17q; KDM6A, lysine demethylase 6A; LCA, large cell anaplastic; MLL3, mixed lineage leukemia protein 3; MYC, cytoplasmic MYC proto-oncogene; MYCN, nuclear MYC proto-oncogene; OTX2, orthodenticle homeobox 2; PTCH1, patched-1; SMARCA4, SWI/SNFrelated, matrix-associated, actin-dependent regulator of chromatin, subfamily A member 4; SMO, smoothened; SNCAIP, synuclein alpha-interacting protein; SUFU, suppressor of fused; TP53, tumor protein 53.

The current mainstay for management of medulloblastoma starts with surgical resection. The intensity of post-surgical treatment, i.e., with craniospinal irradiation (CSI) and adjuvant chemotherapy, is determined by factors that divide patients into average- and high-risk treatment groups (Table 2) [23]. Average-risk patients (defined as children older than 3 years of age with near total resection of tumor and the absence of metastatic disease) have an expected 5-year overall survival of $~ 85 \%$ [24-26]. They are typically treated with 23.4 Gy craniospinal irradiation followed by adjuvant chemotherapy with cisplatin, vincristine, and either cyclophosphamide or lomustine [25]. Patients with high-risk tumors (arising in children younger than 3 years of age with less than near total tumor resection and/or metastatic disease at presentation) have a survival closer to 60-70\% [26-28]. They typically receive higher CSI doses of 36-39 Gy, followed by adjuvant chemotherapy with cisplatin, vincristine, and cyclophosphamide [24,29,30]. However, recent studies have highlighted the need for subgroup-specific treatment stratification. For example, in group 3 tumors alone, the addition of carboplatin to adjunctive chemotherapy dramatically improved overall survival from $54 \%$ to $73 \%$ [29]. 
Table 2. Patient risk stratification.

\begin{tabular}{ccc}
\hline & Average Risk & High Risk \\
\hline Age at diagnosis & $\geq 3$ years old & $<3$ years old \\
Extend of post-operative disease (by MRI) & $\leq 1.5 \mathrm{~cm}$ & $>1.5 \mathrm{~cm}$ \\
Presence of metastasis & $\mathrm{No}$ & Yes \\
5-year event-free survival & $85 \%$ & $60-70 \%$ \\
Intensity of craniospinal irradiation & $23.4 \mathrm{~Gy}$ & $36-39 \mathrm{~Gy}$ * \\
Adjuvant chemotherapy & cisplatin, vincristine, & cisplatin, vincristine, \\
& cyclophosphamide & cyclophosphamide, and \\
& or lomustine & lomustine
\end{tabular}

* Children under age 3 are treated with radiation-sparing or delayed radiation therapy due to the devastating sequelae of whole neuroaxis radiation on neurocognitive development [31-33]; MRI, magnetic resonance imaging; Gy, grays.

Similarly, infants represent a unique group of high-risk patients that have necessitated delayed radiation therapy and treatment with multi-agent chemotherapy followed by autologous hematopoietic stem cell rescue and methotrexate [31-33]. Radiation dose reduction has the important benefit of mitigating treatment-related neurocognitive deficits [34]. However, this approach has provided better outcomes for children with gross total resection with an absence of metastatic dissemination compared to patients with residual or metastatic disease [35,36].

In this review, we discuss medulloblastoma using international genome-based studies to explore mutations within critical signaling pathways that result in the unique protein profile signatures distinguishing each subgroup [11-20]. We provide subgroup-specific demographic and prognostic data with a discussion on the potential diagnostic and predictive markers that may be used for both prognostication and treatment purposes. These include a review of changes in the expression of non-coding RNAs that have been found to associate with MB. We further introduce potential new therapeutic options derived from thorough exploration of the molecular basis for each subgroup, including a brief overview of anti-neoplastic therapies currently in pre-clinical and/or clinical trials.

\section{Wingless (WNT) Medulloblastoma}

The WNT subgroup characterizes approximately $10 \%$ of medulloblastoma cases $[13,37,38]$. These tumors typically arise in the midline, away from the cerebellum in the dorsal brainstem from progenitor cells originating in the lower rhombic lip during cerebellar development (Figure 1) [39]. Peak age of onset is between 10 and 12 years with equal incidence in males and females; it is rarely ever encountered in infants [13]. Patients with this subgroup are distinguished from all other MB subtypes given their classic histology and distinctly favorable prognosis, with a 5-year overall survival exceeding $95 \%$ (Figure 2) $[7,13,37,40]$. Even patients presenting with metastasis in $5-10 \%$ of cases experience good prognosis (Table 1) [22].

The Wingless (WNT) signaling pathway is highly conserved and critical to normal neurologic development [41,42]. Via the canonical pathway, WNT binds to its primary receptor complex, Frizzled (Fz) and LRP5/6, which recruits and phosphorylates Dishevelled (DVL), in turn leading to inactivation of a multi-protein complex (the $\beta$-catenin destruction complex) responsible for $\beta$-catenin degradation [41,43,44]. $\beta$-Catenin is then free to translocate to the nucleus to interact with T-cell factor/lymphoid enhancer factor-1 (TCF/LEF-1) transcription factors, which activate cell proliferation and survival genes, such as $c-M y c$ and cyclin D1 [5,41,44]. In the absence of WNT, the destruction complex, consisting of AXIN1, adenomatous polyposis coli (APC), casein kinase $1 \alpha(\mathrm{CK} 1 \alpha)$, and glycogen synthase kinase $3 \beta$ (GSK3 $\beta$ ), inactivates $\beta$-catenin via phosphorylation at key serine residues, leading to subsequent polyubiquitination and degradation [41,45]. In most sporadic forms of WNT medulloblastoma, a high frequency of mutations have been identified in the proto-oncogene encoding $\beta$-catenin on chromosome 6 , i.e., CTNNB1 $[11,46]$. These mutations cluster around key phosphorylation sites that render $\beta$-catenin resistant to degradation, thus 
leading to constitutive activation of proliferative nuclear signals and subsequent neoplastic transformation [5,47-49].

\subsection{Targeting WNT/ $\beta$-Catenin Signaling}

Given the WNT subgroup possesses the best prognostic profile amongst medulloblastoma patients, targeted therapeutics that have shown promise in pre-clinical studies have yet to find their way to clinical trials. The first identified inhibitor was a derivative of the non-steroidal anti-inflammatory drug, celecoxib, i.e., OSU-03012 (AR-12), originally designed as a PDK1 inhibitor. By specifically inhibiting GSK-3 $\beta$ phosphorylation and inactivation, AR-12 triggered apoptosis and cell cycle arrest in D283 and D324 cells. Oral supplementation of AR-12 to D283 xenograft mice resulted in significantly reduced tumor volume and reduced WNT target proteins, $\beta$-catenin, c-Myc, and cyclin D1 levels [50]. Next, ginkgetin was identified, a natural bioflavonoid isolated from the Chinese plum-yew, which inhibited AXIN2, cyclin D1, and survivin, and induced cell cycle arrest at the $\mathrm{G}_{2} / \mathrm{M}$ phase in DAOY and D283 cells [51]. Similarly, in a time- and dose-dependent manner, curcumin inhibited growth of DAOY cells [52]. Finally, norcantharidin, a natural terpenoid secreted by blister beetles, demonstrated anti-neoplastic properties in medulloblastoma cells by inhibiting phosphatase 2A (PP2A), which is involved in $\beta$-catenin stability [53]. Moreover, norcanthardin also inhibited nuclear $\beta$-catenin translocation, induced $\mathrm{G}_{2}$ cell cycle arrest, and activated apoptosis in vitro and in vivo [54].

As opposed to other subgroups with more unfavorable survival profiles, focus for WNT patients has instead shifted to limiting treatment-related neurocognitive and endocrinologic sequelae secondary to direct craniospinal irradiation during critical years of growth, which can include growth delay, thyroid dysfunction, hyperprolactinemia, and gonadal damage [55]. Strong efforts are now underway to potentially limit cytotoxic therapies in an effort to improve post-treatment quality of life [23,56,57]. In the PNET 5 MB trial (NCT02066220), children with standard risk MB, i.e., near-total resection, $\beta$-catenin nuclear staining, and non-metastatic, are receiving reduced-intensity chemotherapy ( 6 cycles vs. 8 cycles) vs. concurrent carboplatin during radiotherapy [57]; in two other concurrent active trials (NCT01878617 and NCT02724579), WNT patients are being treated with reduced craniospinal irradiation + limited targeted boost to tumor bed and reduced chemotherapy (with cisplatin, vincristine, and lomustine) (Table 3) [57]. The aim of all three trials is to determine if these patients with lower risk can fare equally well with a more tailored approach to their radio-chemotherapy regimens.

\subsection{Therapeutically Activating WNT/ $\beta$-Catenin Signaling}

Contrary to the primary held mechanism for WNT tumorigenesis via constitutive $\beta$ catenin activation, some studies have shown that an overexpression of $\beta$-catenin may actually lead to anti-neoplastic effects. For example, in transformed epidermal keratinocytes [58] and colorectal cancer cells [59], overexpression of $\beta$-catenin led to cell cycle arrest at $\mathrm{G}_{2} / \mathrm{M}$ and subsequent apoptosis. In MB cell lines, transient overexpression of $\beta$-catenin resulted in specific cell cycle arrest at the $\mathrm{G}_{2} / \mathrm{M}$ phase of ONS-76 cells (SHH-type) and a reduced in PTCH1 and SMO in UW473 cells (group 3); all subtypes of cell lines experienced a reduction in colony formation [43]. Subsequently, in an SMO activation murine model of SHH MB, WNT activation was shown to reduce cell proliferation and tumor size and prolong survival [60]. More recently, in patient-derived group 3 and $4 \mathrm{MB}$ brain tumor initiating cells (BTIC), ectopic WNT activation reduced cell proliferation, self-renewal, secondary tumor sphere formation, and orthotopic tumor burden with improved xenograft survival. On the basis of single-cell RNA sequencing, the authors discovered that a subset of WNT active cells within groups 3 and 4 exhibited decreased proliferative and self-renewal properties. Interestingly, the WNT gene signature within these cells, i.e., elevated Axin 2 and reduced Bmi1 and Sox2, when isolated in group 3 patients, was predictive of longer survivorship and improved overall prognosis [61]. These findings suggest a paradigm shift in potentially exploiting WNT activation in the treatment of non-WNT tumors. 
Table 3. Current clinical trials in medulloblastoma.

\begin{tabular}{|c|c|c|c|}
\hline Clinical Trial & Subgroups & Interventions & Phase \\
\hline NCT01878617 & All & $\begin{array}{l}\text { WNT: low dose CSI and lower dose cyclophosphamide } \\
\text { SHH: vismodegib after standard chemotherapy } \\
\text { G3/G4: adding permetrexed + gemcitabine to standard } \\
\text { chemotherapy } \\
\text { G3/G4: reduced dose cyclophosphamide }\end{array}$ & II \\
\hline NCT02066220 & WNT & $\begin{array}{l}\text { Low-risk: radiotherapy without carboplatin and } \\
\text { reduced-intensity maintenance chemotherapy } \\
\text { Standard-risk: radiotherapy with carboplatin and maintenance } \\
\text { chemotherapy }\end{array}$ & $\mathrm{II} / \mathrm{III}$ \\
\hline NCT02359565 & Recurrent or Refractory MB & Pembrolizumab (MK-3475) every 21 days for 34 cycles & I \\
\hline NCT02644460 & Recurrent or Refractory MB & $\begin{array}{l}\text { Abemaciclib twice daily for } 28 \text { days with dose escalation for up to } \\
22 \text { years }\end{array}$ & I \\
\hline NCT02724579 & WNT & $\begin{array}{l}\text { Reduced CSI and no vincristine during radiotherapy followed by } \\
\text { reduced-dose maintenance chemotherapy }\end{array}$ & II \\
\hline NCT03130959 & Recurrent or Refractory MB & $\begin{array}{c}\text { A: Nivolumab } \\
\text { B: Nivolumab + Ipilimumab }\end{array}$ & II \\
\hline NCT03155620 & Recurrent or Refractory MB & Targeted therapy based on genetic testing & II \\
\hline NCT03173950 & Recurrent & Nivolumab weekly for 16 doses & II \\
\hline NCT03213678 & Recurrent MB & Samotolisib twice daily for 28 days for up to 2 years & II \\
\hline NCT03434262 & Recurrent or Refractory MB & $\begin{array}{l}\text { SHH: Ribociclib + Sonidegib } \\
\text { WNT/SHH: Ribociclib + Trametinib } \\
\text { G3/G4: Ribociclib + gemcitabine }\end{array}$ & I \\
\hline NCT04023669 & Recurrent or Refractory MB & $\begin{array}{l}\text { All: Prexasertib + cyclophosphamide monthly up to } 24 \text { months } \\
\text { G3/G4: Prexasertib + gemcitabine monthly up to } 24 \text { months }\end{array}$ & I \\
\hline
\end{tabular}

\section{Sonic Hedgehog (SHH) Medulloblastoma}

Sonic hedgehog medulloblastomas (SHH MB) comprise approximately $30 \%$ of all $\mathrm{MB}$ and arise in the cerebellum from granule neuron precursor cells due to constitutive activation of the sonic hedgehog signaling pathway (Figure 1) [38,39]. The five-year overall survival of SHH MB patients is $\sim 70 \%$. However, as discussed below, survival of these patients varies significantly due to differences in their mutation status. SHH-MB occur most often in infants ( $<3$ years of age) and adults ( $>17$ years of age), with a smaller fraction of cases occurring during childhood and adolescence. SHH MB is the best genetically characterized form of $\mathrm{MB}$, with nearly all SHH MB having either germline or somatic mutations in genes associated with hedgehog signaling (Figure 2).

In wild-type cells, hedgehog signaling is activated by binding of ligand (Desert, Indian, or Sonic) to the cell surface receptor Patched (PTCH). Binding of ligand to PTCH increases the expression and activity of the seven-membrane spanning receptor Smoothened (SMO) in the primary cilium where it blocks the action of Suppressor of fused (SUFU), which sequesters GLI transcription factors in the cytoplasm. As a consequence of SMO activation, GLI transcription factors translocate into the nucleus where they activate transcription of hedgehog target genes. In SHH MB, mutations occur at different points along the hedgehog signaling pathway, including deletion or loss of function mutations in PTCH1 ( 40\%) or SUFU ( 10\%), gain of function (activating) mutations in SMO (9\%), or amplification of GLI2 $(6 \%)[62,63]$. As a result of these mutations, most SHH MB are not dependent on ligand activation of the hedgehog pathway. However, in a small percentage of childhood and adolescent SHH MB, Sonic is amplified. PTCH1 mutations occur in all age groups, whereas SUFU and SMO mutations are more frequent in infants and adults, respectively [63]. GLI2 
mutations occur in children, but they have not been observed in infant or adult SHH MB [63].

In addition to hedgehog signaling mutations, $\mathrm{SHH} \mathrm{MB}$ exhibit a wide range of mutations, including mutations in MYCN, TP53, TERT, and PTEN [63]. Loss or silencing of PTEN, which activates PI3K/AKT/mTOR signaling, has been reported to drive nonconical activation of GLI transcription factors and aberrant hedgehog signaling [64,65]. TP53 status of SHH MB is highly significant because TP53 mutations in these tumors are highly correlated with patient outcomes. Lack of TP53 mutations in young children and adults is associated with good outcome (5-year OS > 80\%). In contrast, TP53 mutations, which frequently occur in older children (median age of 9 ), are associated with poor overall survival (40\% 5-year OS) [63]. Notably, TP53 mutations are found in approximately two-thirds of children over 6 years of age who die of SHH MB, and over $50 \%$ of TP53 mutations in SHH $\mathrm{MB}$ are germline mutations [66].

\subsection{Molecular Characteristics and Subtypes of SHH MB}

SHH-MB exhibit four histopathologies: classic, desmoplastic/nodular (DN), large cell/anaplastic (LC/A), and medulloblastoma with extensive nodularity (MBEN). DN and classic occur most often in SHH MB (35 to $45 \%$ for each histology). LC/A and MBEN occur at frequencies of 15 and 10\%, respectively. Histology alone is insufficient for predicting patient outcome or selection of treatment options. Recently, SHH MB were further subdivided into four subtypes $(\alpha, \beta, \gamma, \delta)$ on the basis of their gene expression profiles and DNA methylation status (Table 1) [22]. SHH $\alpha, \mathrm{SHH} \beta, \mathrm{SHH} \gamma$, and $\mathrm{SHH} \delta$ were found to account for $29,16,21$, and $34 \%$ of SHH MB, respectively. SHH $\alpha$ carries very high risk of dying and exhibits classic, DN, or LC/ A histology. SHH $\beta$ carries high risk (lower than $\mathrm{SHH} \alpha$ ) and exhibits classic or DN histology. $\mathrm{SHH} \gamma$ carries low risk and exhibits classic, DN, or MBEN histology. SHH $\delta$ carries average risk and exhibits classic or DN histology [22].

$\mathrm{SHH} \alpha$, which has the worst outcome, occurs primarily in childhood and adolescence (3 to 16 years of age). This subtype exhibits MYCN, GLI2, and YAP1 amplifications at frequencies of $20 \%, 16 \%$, and $8 \%$, respectively. TP53 mutations occur frequently in $\mathrm{SHH} \alpha$ $(35 \%)$, and thus far is the only identified negative prognostic marker for SHH MB. Infant SHH MB are comprised mainly of SHH $\beta$ and $\mathrm{SHH} \gamma$ subtypes. Of the two subtypes, $\mathrm{SHH} \beta$ exhibits poorer outcome than $\mathrm{SHH} \gamma$, possibly due to a higher frequency of metastasis by $\mathrm{SHH} \beta(33 \%)$ than $\mathrm{SHH} \gamma(9 \%)$. SHH $\beta$ frequently possesses PTEN deletions $(25 \%)$ and multiple focal amplifications. SHH $\gamma$ exhibits the lowest mutational load of SHH MB. SHHס, which occur primarily if not exclusively, in adults, has favorable outcome. It often carries TERT promoter mutations (90\%) that elevate telomerase [22].

\subsection{Challenges in Treating SHHMB}

Although the five-year overall survival of SHH MB is $70 \%$, treatment of many SHH MB patients, in particular infants, is very challenging. The standard of care for the treatment of SHH MB is similar to that used for all MB patients over the age of 3. For infants, radiation-sparing therapy is used to minimize the cytotoxic effects on the developing brain. Currently, there are several ongoing clinical trials for SHH MB (Table 3). In addition, a recent clinical trial (SJYC07) reported that a subset of SHH MB patients (SHH-II) according to their DNA methylation status exhibited improved progression-free survival [67]. Rather than providing a comprehensive overview of new treatment options for SHH MB, below we focus on SMO inhibitors to illustrate the challenges faced when treating SHH MB with small molecule inhibitors. Broader coverage of treatment options for patients with $\mathrm{SHH}$ MB has been reviewed recently [68].

Multiple studies, including several recent large-scale studies, have demonstrated that survival of all MB patients, including those with SHH MB, are highly dependent on the molecular characteristics of the tumor $[22,62,63]$. In the case of SHH MB, targeted therapy has focused heavily on the SMO inhibitors vismodegib and sonidegib because almost all 
SHH MB patients have mutations in genes directly associated with aberrant hedgehog signaling. Both SMO inhibitors have been evaluated in MB clinical trials [69-71]. In a meta-analysis of phase I and phase II clinical trials, the overall response of patients with SHH MB to these inhibitors was 37\%, with sonidegib exhibiting at least threefold higher efficacy than vismodegib [69]. Not surprisingly, there were no positive responses observed in patients with other types of MB.

Although the clinical responses to SMO inhibitors are encouraging, the long-term efficacy of these inhibitors is limited by the development of resistance in at least $20 \%$ of those who had responded favorably to SMO inhibitors. Resistance appears to be due, at least in part, to mutations in the drug binding pocket of SMO that interfere with drug binding $[72,73]$. Additionally, SHH MB patients who become resistant to vismodegib are likely to exhibit cross-resistance to sonidegib [74]. As a result, efforts are underway to develop new SMO inhibitors, including those that inhibit mutant drug-resistant SMO $[75,76]$. The use of vismodegib and sonidegib is also contraindicated for pediatric patients because these drugs can hinder bone development and cause irreversible growth plate fusions, leading to short stature and disproportionate growth [77]. A further limitation of SMO inhibitors is expected for $\mathrm{SHH} \mathrm{MB}$ patients with mutations downstream of $\mathrm{SMO}$, in particular for those with SUFU loss of function mutations and those with GLI2 amplification, which occur in 16 and $6 \%$ of SHH MB patients, respectively [73]. Moreover, recent evidence collected from the study of genetically engineered mouse (GEM) models of SHH MB has led to the suggestion that treatment with vismodegib can epigenetically silence SUFU and drive tumor cell proliferation [78].

Another challenge in the treatment of SHH MB with small molecule inhibitors is tumor heterogeneity. In tumors with significant heterogeneity, which is the case for most tumors, the responses of the different tumor cell populations can vary widely. This is especially true of the tumor-initiating cell population of the tumor, which is often less sensitive to the inhibitor than the bulk of the tumor. This problem was laid bare in the study of a GEM model of SHH MB. In this model, irradiation of $\mathrm{PTCH}^{+/-}$mice resulted in the vast majority of the mice $(\sim 80 \%)$ developing tumors that closely resembled human SHH MB, enriched in the stem cell transcription factor SOX2 [79,80]. Analysis of the tumors from this GEM model indicated that the tumors were hierarchically organized with a small population $(<5 \%)$ of SOX2-positive $\left(\mathrm{SOX}^{+}\right)$cancer stem cells that self-renewed, yet proliferated infrequently [79]. This rare, label-retaining $\mathrm{SOX}_{2}{ }^{+}$stem cell population gave rise to $\mathrm{Dcn}^{+}$ progenitor cells, which proliferated actively and gave rise to non-proliferating/post-mitotic $\mathrm{NeuN}^{+}$differentiated cells. Collectively, the proliferative progenitor population and their differentiated derivatives accounted for the bulk of the tumor. Treatment of these tumorbearing mice with vismodegib or cytarabine (Ara C) targeted the proliferating population and spared the infrequently proliferating $\mathrm{SOX}^{+}$cell population. As a result, while the tumor did regress, upon drug discontinuation, tumors regrew [79]. The critical role of the $\mathrm{SOX}_{2}{ }^{+}$cell population in these tumors was further demonstrated with the finding that $\mathrm{SOX}_{2}{ }^{+}$cells exhibited substantially higher tumor-initiating capacity than $\mathrm{SOX} 2^{-}$cells. Moreover, lineage-tracing studies have directly implicated a rare $\mathrm{SOX}_{2}{ }^{+}$granule neuron precursor population as the cell of origin of SHH MB [81], and MB patients with high levels of SOX2 have poorer overall survival [79].

\subsection{Meeting the Challenges Posed by SOX2 ${ }^{+}$SHH MB Cancer Stem Cells}

Meeting the major challenge of tumor recurrence for $\mathrm{SHH} \mathrm{MB}$ will require targeting the stem cell population of $\mathrm{SOX}_{2}^{+}$cells. One approach to addressing this daunting challenge is to identify the vulnerabilities of the population of infrequently proliferating SOX2 ${ }^{+}$ tumor cells. Normal SOX2 ${ }^{+}$stem cells are present in many developing tissues $[82,83]$. $\mathrm{SOX}^{+}$stem cells during development give rise to highly proliferative progenitor cell populations, which then generate tissue-specific differentiated cells that constitute the bulk of the developing tissue [82,83]. Importantly, elevating SOX2 in the progenitor population during development reduces their proliferation, whereas interfering with SOX2 function 
in the stem cell compartment enhances proliferation. These studies indicate that SOX2 levels are used by both normal stem cells and cancer stem cell populations to control proliferation [84].

Our recent studies have shown that elevating SOX2 from an inducible promoter in a wide range of human tumor cell lines, including the $\mathrm{SHH} \mathrm{MB}$ cell lines, can lead to a dramatic reduction of proliferation both in vitro and in vivo [85-88]. In a flank tumor model using ONS76 MB cells, elevation of SOX2 from an inducible promoter led to a reversible state of tumor growth arrest [88]. Upon removal of the inducer, SOX2 levels returned to baseline and tumor growth resumed to match their uninduced counterparts. This reversible SOX2 growth-arrested tumor model system parallels the behavior of the rarely proliferating $\mathrm{SOX} 2^{+} \mathrm{SHH} \mathrm{MB}$ cancer cells discussed above.

This SOX2-inducible model system could be exploited to determine the molecular mechanism by which elevation of SOX2 halts tumor growth. Insights into the mechanisms that limit growth of the tumor could help develop clinical strategies that prevent the SOX2 ${ }^{+}$ SHH MB tumor-initiating cells from repopulating the tumor after completion of standard of care. Second, this SOX2-inducible model system could be used as a platform to screen a library of drugs, particularly FDA-approved drugs, for their ability to eradicate SOX2 growth-arrested tumor cells in vivo. Progress on either of these experimental approaches could help develop novel strategies to either delay or prevent SHH MB recurrence, which occurs with an incidence of $\sim 25 \%$ and is nearly always fatal $[89,90]$.

\section{Group 3 Medulloblastoma}

Group 3 tumors represent roughly 25\% of all MB cases and arise from nestin-positive neural stem cells in the cerebellar vermis (Figure 1) [38,91,92]. This subgroup shows a male predominance (male to female ratio 2:1) and occurs almost exclusively in infants and young children, with the highest rates of diagnosis occurring between ages 3 and 5 years [22,41,42]. Group 3 MBs mostly demonstrate either classic or LCA histology and frequently present with high rates of metastasis at diagnosis (up to $50 \%$ of patients). These high risk factors, i.e., young age, metastatic spread at diagnosis, presence of MYC amplifications, and prevalent LCA histology, all contribute to these tumors having the worst prognosis of any subgroup with an overall 5-year survival of $<50 \%$, especially in MYC-amplified tumors (Figure 2) [3,41,93,94].

\subsection{Molecular Characteristics and Subtypes of Group $3 \mathrm{MB}$}

The biology of group 3 tumors is not well established. These tumors likely originate from a neural/cerebellar stem cell population [91,95]. Unlike WNT/SHH-driven MBs, group 3 tumors are genetically heterogenous, and extensive integrated genomic and molecular analyses have yet to identify a common driver pathway that defines the group 3 subgroup. Nevertheless, somatic MYC amplification (17\%) is most frequently observed, often concurrent with genomic rearrangement of PVT1-MYC fusion [16]. Although recurrent somatic mutations are rarely encountered, genetic mutations in four genes, SMARC4, KBTBD4, CTDNEP1, and KMT2D, have been identified in over 5\% of cases [62]. Small subsets of these tumors are driven by amplifications of $M Y C N(5 \%)$ and the transcription factor OTX2 (3\%) [62]. Enhancer hijacking events leading to the activation of GFI1/GFI1B are present in 15-20\% of group $3 \mathrm{MBs}$ and may also be important driver events for this subgroup [96]. Other genetic aberrations include copy number alterations in TGF $\beta$ pathway genes and mutations in NOTCH signaling genes [97]. Finally, cytogenetic alterations are abundantly seen in group 3 tumors. The most common cytogenetic abnormalities in this subgroup include the gain of $17 q(58 \%)$ and loss of $17 p(55 \%)$, along with a loss of $16 q$ $(42 \%), 10 q(43 \%)$, and $9 q(21 \%)$ and gain of $7(39 \%)$ and $1 q(41 \%)[41,98]$.

Recently, two newer molecular classifications have been proposed for group $3 \mathrm{MB}$. One classification is based on methylome data that distinguishes a high-risk subtype with frequent MYC amplifications [99]. The second defines three primary subtypes: $3 \alpha$ (occurring in infants and young children with frequent metastasis), $3 \beta$ (occurring in older children 
displaying OTX2 gain, DDX31 loss, and high GFI1/GFI1B amplification/activation), and $3 \gamma$ (occurring in infants with MYC amplification) (Table 1) [22].

\subsection{Risk Stratification, Prognostic Biomarkers, and Treatment Approaches}

A recent consensus proposal recommended a more refined risk stratification for $\mathrm{MB}$ tumors in pediatric patients. This consensus proposed four categories: low ( $>90 \%$ survival), standard (75-90\% survival), high (50-75\% survival), and very high risk ( $<50 \%$ survival) MBs [100]. The non-metastatic group $3 \mathrm{MBs}$ with no MYC amplification are included in standard-risk population. However, the metastatic group $3 \mathrm{MBs}$ with MYC amplification are included in very high-risk stratification. The risk identification of non-metastatic group 3 with MYC amplification or LCA histology or isochromosome 17q needs to be further clarified.

Our limited understanding of tumorigenesis mechanisms for group 3 tumors has arrested the development of targeted treatment strategies. However, currently, for newly diagnosed patients, the NCT01878617 trial offers a risk-adapted treatment strategy: intermediateand high-risk patients are exposed to new chemotherapy agents (pemetrexed and gemcitabine) after standard chemotherapy and risk-adapted radiotherapy. For recurrent and refractory $\mathrm{MB}$ patients, two trials offer treatments based on molecular subgrouping. In NCT04023669, prexasertib (LY2606368), a targeted checkpoint kinase 1/2 (CHK1/2) inhibitor, is administered in combination with cyclophosphamide or in combination with gemcitabine for group 3 MBs. The trial NCT03434262 investigates the combination of the cyclindependent kinase inhibitor ribociclib and gemcitabine for group 3 MBs (Table 3) [101].

The use of alternative adjuvant chemotherapy for high-risk MB is being actively pursued. In a recent prospective randomized phase 3 clinical trial (NCT00392327), therapy intensification with carboplatin as a radiosensitizer improved event-free survival from $54 \%$ to $73 \%$ at 5 years for children with high-risk group $3 \mathrm{MB}$. On the basis of these results, concurrent treatment of carboplatin with radiotherapy is recommended for children with high-risk group 3 MB [29].

Immunotherapy has recently gained attention as a novel adjunctive therapy for recurrent, progressive, or refractory MB tumors. The challenge has always been overcoming the intricate system of barriers that complicates delivery and efficacy [102]. However, several immunotherapeutic approaches have reached clinical trials for $\mathrm{MB}$, particularly immune checkpoint inhibitors that target the immunosuppressive brain tumor microenvironment [103]. To date, the most notable examples of effective immune checkpoint inhibitors are antibodies against cytotoxic-T-lymphocyte antigen 4 (CTLA-4) and the programmed cell death protein (PD-1) and its ligand PD-L1. Currently, there are three active phase $1 / 2$ clinical trials that aim to evaluate the use of PD-1/PD-L1 inhibitors in MB: pembrolizumab (NCT02359565), nivolumab (NCT03173950), and nivolumab in combination with the CTLA-4 inhibitor ipilimumab (NCT03130959) (Table 3).

\subsection{Pre-Clinical Group 3 Models Identify Druggable Pathways}

Our lack of clear understanding on the pathophysiology triggering group 3 tumors has also hampered the generation of spontaneous animal models for this subgroup. Given the high frequency of $M Y C$ mutations and their influence on prognosis in group $3 \mathrm{MB}$, models of MYC-driven tumors have emerged. While MYC overexpression alone is insufficient in triggering tumors, combining it with inactivating mutations of the tumor suppressor TP53 results in tumors exhibiting an LCA histology with similarity in gene expression signatures to group 3 tumors [96,104-106]. The generated tumors are enriched for genes targeting PI3K/mTOR. Drug screening within this model identified histone deacetylase inhibitors (HDACIs, such as panobinostat) demonstrating synergistic activity with phosphatidylinositol 3-kinase inhibitors (PI3KI) via activating the expression of the FOXO1 tumor suppressor [107]. Another mouse model utilizing human neural stem and progenitor cells harboring transformed MYC, dominant-negative TP53, and constitutively active AKT and $h T E R T$ revealed tumor sensitivity to cyclin-dependent kinase (CDK) inhibitors, such as 
Palbociclib [108]. These studies not only highlight the critical role MYC played but also revealed novel downstream therapeutic targets.

However, TP53 mutations are rarely detected in group 3 tumors at diagnosis [66]. Thus, such mouse models that require TP53 mutation may be of limited relevance for understanding human tumor biology and future therapy development. A recent study by Tao et al. reported that $\mathrm{SOX}^{+}$cells of the early postnatal cerebellum can be transformed by MYC alone, resulting in tumors resembling human group $3 \mathrm{MB}$ based on histology and gene-expression profiling. Using this model, they also identified lactate dehydrogenase A (LDHA) as a novel therapeutic target for group $3 \mathrm{MB}$ [109]. A separate study overexpressed MYC and GFI1 in CD133+ cells triggering group $3 \beta$ tumors [96].

Despite the central role that MYC plays in high-risk group 3 tumors, MYC has proven thus far to be therapeutically undruggable because of its complex structure and nonenzymatic/pleotropic nature. However, targeting epigenetic regulators of MYC may provide a promising alternative. Bromodomain and extra-terminal (BET)-containing proteins promote gene transcription by recognizing side chain acetylated lysine on open chromatin and have been shown as potential targets of MYC or MYCN transcription [110]. BET bromodomain inhibitors, such as JQ1, inhibited in vitro cell proliferation and prolonged survival in MYC-amplified MB xenografts [111]. Recent preclinical studies in cell lines and xenograft models of group $3 \mathrm{MB}$ also identified that BET protein inhibitors not only had single agent antitumor efficacies, but also synergistic efficacies with PI3K/mTOR and CDK2 inhibitors [112].

Similarly, we recently identified increased activation or overexpression of the protein synthesis pathway in the progression and resistance of highly aggressive MYC-amplified forms of MB [113]. Using genetic and pharmacologic approaches, we found that combined inhibition of MYC transcription (by BET protein inhibition) and mTOR signaling had a synergistic anti-tumor effect against MYC-driven group 3 MB [113]. Therefore, the MYC/mTOR axis could be an attractive therapeutic target for group $3 \mathrm{MB}$. Other important metabolically active druggable pathways in group $3 \mathrm{MBs}$ include the folate and purine metabolism pathways [114], angiogenesis pathways [115], and CD47 [116]. According to these studies, the combined application of the folate synthesis inhibitor pemetrexed and nucleoside analog gemcitabine inhibited tumor cell growth [114], as did the humanized anti-CD47 antibody (Hu5F9-G4) [116].

In summary, most preclinical in vitro and murine models resemble MYC-activated $\mathrm{MBs}$, and the field lacks adequate representation of heterogeneity within group 3 tumors. In fact, all existing group $3 \mathrm{MB}$ cell lines are MYC-amplified. Model systems exploring tumorigenic mechanisms of non-MYC-amplified group 3 are needed. Most preclinical therapeutic studies focus on the inhibition of PI3K and mTOR signaling pathways, evaluate the synergistic activity between histone deacetylase inhibitors and PI3K inhibitors, assess the efficacy of CDK or BET bromodomain inhibitors, and test the effectiveness of antivascularization therapies. Such experiments are no longer confined to preclinical model systems, and numerous early phase clinical trials have started to explore these promising avenues in recurrent/refractory MBs.

\section{Group 4 Medulloblastoma}

Group $4 \mathrm{MB}$ is the most-prevalent subgroup, accounting for almost $40 \%$ of all $\mathrm{MB}$ tumors, frequently seen in children aged 5-10 years and rarely in infants [22,38]. Arising within the fourth ventricle from unipolar brush cells, group 4 tumors occur three times more often in males than females (Figure 1) [13,91,92,117]. Thus, this subgroup has the most skewed distribution amongst all the subgroups. Similar to group 3, the classic and LCA histology are prevalent in these tumors. Patients with average-risk, as determined by the absence of metastasis, have a 5-year overall survival $>80 \%$. However, for the approximately $35-40 \%$ of patients exhibiting metastatic disease at diagnosis (making them high risk), prognosis is poor. Overall, patients with group $4 \mathrm{MB}$ have an intermediate prognosis when treated with standard therapy (Figure 2) $[7,89,100]$. 


\subsection{Molecular Characteristics and Subtypes of Group $4 M B$}

Although group $4 \mathrm{MB}$ is most common in incidence, similar to group 3 tumors, underlying genetic or molecular basis for this disease is not well understood. Gross chromosomal gain (7 and $18 q)$ and losses $(8 p, 10 q$ and $17 p)$ are frequently observed in group 4, particularly isochromosome $17 \mathrm{q}$ (i17q) present in $\sim 80 \%$ of cases. Aberrant $11 p$ and $18 \mathrm{q}$ and complete loss of $\mathrm{X}$ chromosomes (in females) are frequently observed in group $4[13,18,93,98,118]$.

Frequent genetic markers mutated or altered in copy numbers include histone lysine demethylase KDM6 (mutation), histone methyltransferases KMT2D and KMT2C (mutation), OTX2 (amplifications), DDX31 (deletions), CHD7 (mutations), and activation of GFI1/GFI1B expression. These genetic alterations significantly overlap with those associated with group $3 \mathrm{MB}$. However, unlike group 3 tumors where MYC gene is amplified, preferential amplification of $M Y C N$ is observed in group 4 tumors $[7,62,96,119]$. In fact, a certain level of MYCN expression might be required for tumor maintenance. For example, when conditional MYCN ${ }^{\mathrm{T} 58 \mathrm{~A}}$ (stabilized form of MYCN) was induced in neural cells in mouse cerebella from postnatal day 1 through adulthood, mice developed group 4-like tumors [120].

The most frequent genetic mutation seen in group $4 \mathrm{MB}$ occurs in the histone demethylase gene KDM6A, which regulates the H3K27 methylation. As an epigenetic regulator, H3K27 regulates expression of genes that are involved in cell cycle control, differentiation, and pluripotency. Therefore, by preventing H3K27 demethylation, KDM6A mutation might preserve or initiate stem cell-like states in tumor cells. Interestingly, KDM6A seems to be more frequently mutated in boys with $\mathrm{MB}$ compared with girls, which might explain the observed male predominance of this MB subtype [19,121,122]. Another prevalent event in group 4 tumors is CDK6 amplification and overexpression of PRDM6 via enhancer hijacking, which occurs along with SNCAIP duplication $[62,93,119]$.

These mutational analyses along with integrated gene expression and DNA methylation arrays have identified the heterogeneity within group 4 tumors, giving rise to three primary subtypes $\alpha, \beta$, and $\gamma$ (Table 1). Group $4 \alpha$ are enriched for MYCN amplifications, whereas $\beta$ are strongly enriched for SNCAIP duplications and presence of i17q. Group $4 \alpha$ and $4 \gamma$ are strongly enriched for $8 p$ loss and $7 q$ gain. In addition, groups $4 \alpha$ and $4 \gamma$ are enriched for focal CDK6 amplifications [22].

\subsection{Pre-Clinical Group 4 Models Identify Druggable Pathways}

Current standard therapy cures a high proportion of patients with average-risk group 4 MB [68]. A prospective study of average-risk group 4 patients aged 3-17 years treated with surgery, irradiation, and chemotherapy found excellent 5-year progression-free survival $(95.9 \%$ and $88.7 \%)$ for patients treated by two different protocols [123]. However, there are no therapies for high risk metastatic group $4 \mathrm{MBs}$, although upfront metastatic disease are somewhat salvageable with current treatment strategies [27,29]. As metastatic MB is the key risk factor for treatment failure in group $4 \mathrm{MB}$, inclusion of novel agents to the standard first-line treatment need to be considered. Preclinical studies have shown involvement of P13K signaling pathway as a potential driver pathway for recurrent, metastatic MB [97]. Further, absence of a mouse model that mimics human group $4 \mathrm{MB}$ has hampered the identification of novel target or development of new approaches to treat patients with highrisk diseases. However, a recent study showed that group 4 tumors displayed aberrant receptor tyrosine kinase (RTK) ERBB4-SRC signaling. Enforced in utero expression of an activated SRC combined with TP53 inactivation induced murine tumors that resembled group 4 MB [124]. These highly distinct RTK activity profiles distinguishing group 3 and 4 tumors were cross-validated in a non-overlapping, independent mass spectrometry dataset analysis [125]. This model suggested that group 4 MBs could be susceptible to available kinase inhibitors including lapatinib or dasatinib to improve outcomes in children with high-risk group 4 tumors. 


\section{Epigenetic Drivers of MB}

Next-generation sequencing of $\mathrm{MB}$ tumors have shown that besides amplification of $M Y C, M Y C N$, CCND2, and GLI2, mutations in epigenetic regulator, e.g., histone lysine methyltransferase or acetyltransferase (KMT and HAT, also called "writers"); demethylases or deacetylases (KDM, HDAC, also called "erasers"); and members of the polycomb transcriptional repressor complex, PRC2 and PRC1, account for majority of the genetic perturbations in the non-SHH/WNT groups 3 and 4 MBs (Figure 3) $[19,122,126]$. The highest frequency of mutations in histone modifier was found in KDM6A, the H3K27 demethylase described earlier. KDM6A associates with H3-K4 methyltransferases, MLL2 and MLL3, which are also recurrently mutated along with $\mathrm{CHD7}$. Consistent with this, aberrant patters of $\mathrm{H} 3 \mathrm{~K} 4$ and $\mathrm{H} 3 \mathrm{~K} 27$ histone methylation have been found in group 3 and 4 tumors. These altered epigenetic marks are thought to drive cell proliferation and a stem cell-like phenotype in MB [127].

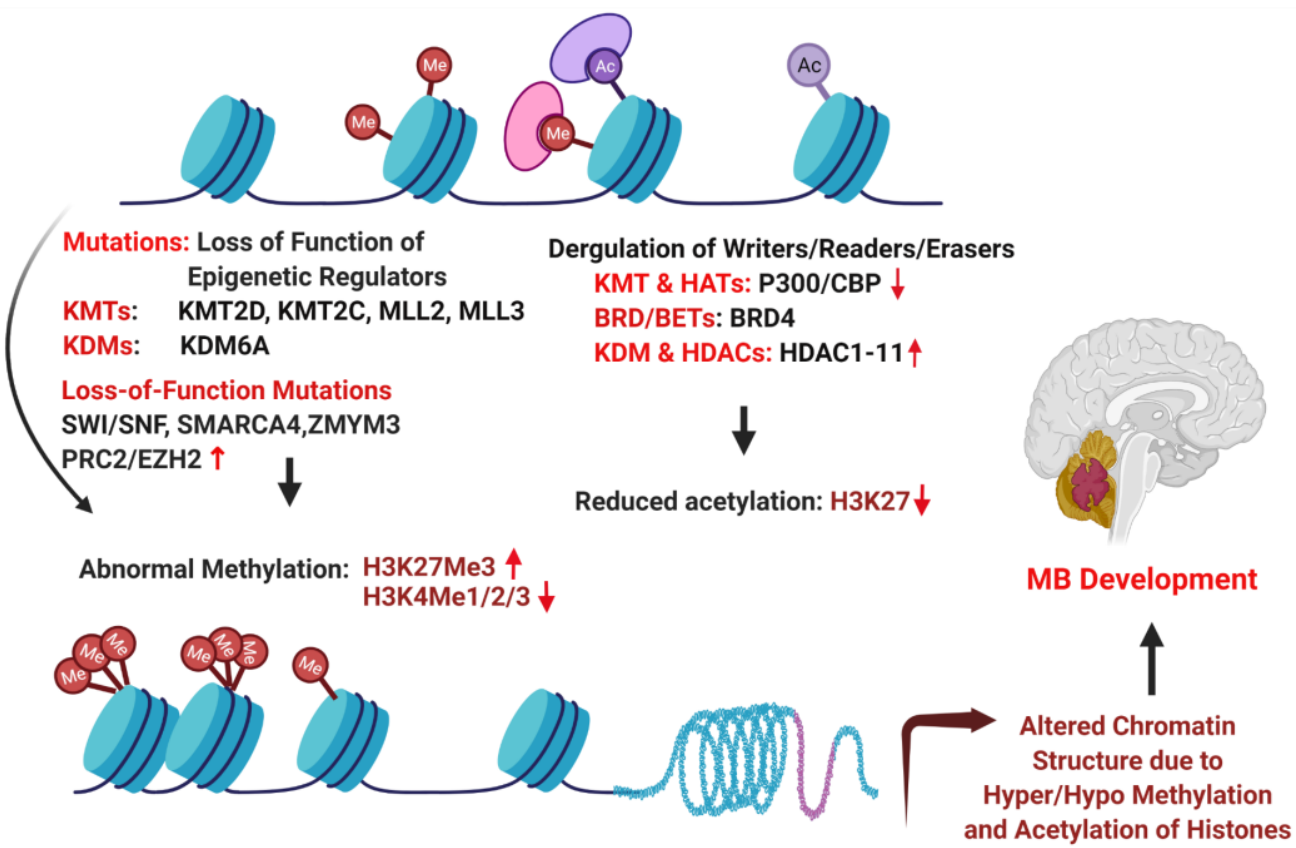

Figure 3. Epigenetic alterations in medulloblastoma. BRD4, bromodomain-containing 4; CBP, CREBbinding protein; EZH2, enhancer of zeste 2 polycomb repressive complex 2 subunit; H3K27Me3, tri-methylated lysine 27 on histone 3; H3K4Me, methylated lysine 4 on histone 3; HDAC, histone deacetylase; KDM6A, lysine demethylase 6A; KMT, lysine methyltransferase; MLL, mixed lineage leukemia protein; SMARCA4, SWI/SNF-related, matrix-associated, actin-dependent regulator of chromatin, subfamily A member 4; SWI/SNF, switch/sucrose non-fermentable chromatin remodeling complex; ZMYM3, zing finger MYM-type-containing 3.

The polycomb repressor complex PRC2 plays an important role in differentiation and maintenance of cell identity. EZH2, the catalytic subunit of the PRC2, is responsible for methylating the lysine 27 of $\mathrm{H} 3$, which contributes to chromatin compaction and transcriptional repression [128]. Studies have shown that a subset of group 3 and 4 tumors, but not SHH and WNT tumors, have high levels of EZH2 expression and H3K27 Me3 marks but low H3K4 methylation, a combination of epigenetic marks consistent with a stem/progenitor cell like identity [127]. Although $E Z H 2$ was thought to be an oncogene, deletion of $E Z H 2$ in mouse and human group 3 cells by CRISPR/cas9 gene editing approaches have resulted in loss of PRC2 complex, accelerating tumor growth [129]. In contrast, in vitro studies in MB cell lines using shRNA or the EZH2 inhibitor suggested that EZH2 had oncogenic activity [130]. Therefore, EZH2 can function as a tumor suppressor or an oncogene in a context-dependent manner. Inactivation of EZH2 was found to accelerate MYC-driven 
group 3 MB by upregulation of GFI1 proto-oncogene. Interestingly, GFI1 is a transcriptional repressor that is upregulated in group $3 \mathrm{MB}$ by enhancer high jacking. GFI1 disruption antagonized the tumor-promoting effects of EZH2 loss; conversely, GFI1 overexpression worked synergistically with MYC to bypass effects of TP53 inactivation in driving MB progression in primary cerebellar neuronal progenitors. Therefore, EZH2, MYC, and GFI1 may combine to drive group $3 \mathrm{MB}$ through concerted mechanisms [96,129].

Another class of epigenetic regulators, BET-containing proteins, binds to acetylated histones in the promoter regions and in turn facilitates recruitment of positive transcription elongation complex-b (P-TEFB), comprising CDK9 and Cyclin T1, to activate transcription elongation [131]. Our recent study showed that CDK9 and BRD4 are upregulated in MB cell lines and in MB mouse model, and targeting CDK9 and BRD4 with small molecule inhibitors significantly decreased cell growth, migration, and gene expression [132]. BRD/BET proteins regulate the expression of the key driver oncogene MYC in group 3 MBs. Several studies have shown that BET inhibitor JQ1 can potently inhibit MB growth in a preclinical model, being currently under clinical trial for many other types of cancers [19,110,111,133,134].

Recurrent mutations in ATP-dependent chromatin remodeling SWI/SNF complex member SMARCA4 have been identified in group 3 subgroups $[19,135]$. SWI/SNF and PRC2 complex exhibit epigenetic antagonism, raising the possibility that PRC2 inhibitors may work well in SWI/SNF mutant MBs [136]. Inactivation of ZMYM3, a histone-binding protein that contributes to gene transcription at the H3K4Me3 mark, occurs exclusively in group 4 MBs. ZMYM3 mutations are often found along with KDM6 mutations and EZH2 expression, suggesting the importance of H3K27/H3K4 modulation in MB [19,137].

\section{Drug Resistance and Recurrence in MBs}

A range of cellular mechanisms, including active efflux of the chemotherapeutic agents and efficient repair of DNA damage by multiple DNA repair pathways, have been proposed to induce chemo- and radio-resistance in tumor cells [138,139]. APE1, a key enzyme responsible for repair of radiation-induced oxidized bases or single-strand breaks via base excision repair pathway, is overexpressed in $\mathrm{MB}$, and its activity is associated with response to radiation and cisplatin in MB patients $[140,141]$. Our recent study demonstrated that APE1 interacts with a chromatin remodeling histone chaperone Facilitates Chromatin Transcription (FACT) complex to facilitate radiation and cisplatin-induced DNA repair in group $3 \mathrm{MB}$ cells in vitro. Notably, MB tissues have elevated levels of post-transitionally modified acetylated APE1 (AcAPE1) and FACT complex, both associated with poor prognosis [142]. Inhibition of FACT with small-molecule CBL0137 (also known as curaxin) sensitized MB cell lines and orthotopic tumors to radiation and cisplatin [142,143]. Curaxin modulates an important pathway for cancer stem cell proliferation, i.e., NOTCH signaling, [144,145]. Recent transcriptome analyses in group $3 \mathrm{MB}$ cells showed that curaxin preferentially suppressed cell cycle and DNA repair-related biological processes. Treatment with curaxin downregulated the expression of hundreds of genes, including MYC and OTX genes that are known to be major activators of highly aggressive MB [142]. Further investigations as to whether curaxin can improve the efficacy of interventions for MB and outcomes in high-risk patients is warranted.

Repair of radiation- and cisplatin-induced DNA double-strand break (DSB) repair are critical to cell survival. DSBs are primarily repaired through homologous recombination (HR) or non-homologous end joining (NHEJ) pathways [146,147]. Therefore, deregulation of proteins or cofactors that control these repair pathways can promote DNA repair and induce drug resistance in cancer. PRKDC is overexpressed in MYC-amplified group 3 cell lines [97,125]. The PRKDC gene encodes the DNA-dependent protein kinase catalytic subunit (DNA-PKcs), which promotes DSBs via NHEJ [148]. The PRKDC inhibitor NU7441 preferentially sensitized MYC-amplified cells to radiation [97]. Similarly, growing evidence supports the importance of arginine methylation by protein arginine methyltransferases (PRMTs) in promoting drug resistance via modulating both HR and NHEJ. Specifically, 
PRMT5 activity was linked with NHEJ repair by methylating and stabilizing p53-binding protein 1, which facilitates NHEJ and promotes cellular survival after DNA damage [149]. PRMT5 is also a regulator of HR-mediated DSB repair, which is mediated through its ability to methylate RUVBL1, a cofactor of the TIP60 complex involved in HR [150]. Our study has demonstrated the overexpression of PRMT5 in MYC-driven primary MB tumors and cell lines compared to non-MYC MB tumors [151]. High expression of PRMT5 was shown to inversely correlate with patient survival. PRMT5 inhibitor EPZ015666 exhibited dose-dependent efficacy in suppressing cell growth and inducing apoptosis in MYC-driven MB [151]. There is evidence that PRMT5 cooperates with pICln to function as a master epigenetic activator of DNA damage response genes ( $R A D 51, B R C A 1$, and $B R C A 2)$ involved in HR and NHEJ [152]. Taken together, these studies have revealed PRKDC and PRMT5 in promoting drug resistance via modulating DSBs repair.

\section{Non-Coding RNAs in MB}

Approximately $2 \%$ of transcribed RNA encodes proteins [153]. The remaining vast majority are non-coding RNAs (ncRNA), encompassing microRNAs (miRNAs), long noncoding RNA (lncRNAs), and circular RNAs (circRNAs). Despite differences in size, structure, and biogenesis, they are integral to nearly every step of gene expression, imposing regulatory control over epigenetic modifications, transcription, splicing, RNA stability, and translation $[154,155]$. In this section, we review the important diagnostic, prognostic, and pathologic roles of these ncRNAs in MB.

\subsection{MiRNA}

MicroRNAs (miRNAs) are approximately 20-22 nucleotides in length and bind to the $3^{\prime}$ UTR of target mRNA to regulate their expression [156]. MiRs possess the capability to both trigger and suppress growth on the basis of the rich network of target proteins affected by their binding. Thus, miRNAs can act as oncogenes or tumor suppressors depending up on their targets and the cellular context [157]. Deregulation of miRs is now considered a hallmark of multiple cancers and unique signatures for various miRs are currently being generated to guide cancer diagnostics and therapies. To define the role of miRs in medulloblastoma, researchers have conducted several studies, with some exploring the status of miRs specifically on chromosome 17p.

In 2008, Ferretti et al. showed for the first time that Hh pathway regulates expression of miRs in MB. More specifically, they showed that miR-125b, miR-324-5p, and miR-326 target SMO and GLI1 [158]. In turn, overexpression of these miRs inhibited tumorigenesis by inhibiting Hh signaling. They further mapped the locus of miR-324-5p to 17p13.1, showing loss in $40 \%$ of human MBs [158]. A follow-up publication profiled $248 \mathrm{miRs}$ in human MBs, revealing a total of 78 miRs to be differentially regulated in MBs, with miR-9 and miR-125a demonstrated as tumor suppressor genes [159]. We showed that activated STAT3 transcription factor mediates upregulation of miR-21 that suppressed protein inhibitor of activated STAT3 (PIAS3), thereby accelerating MB pathogenesis [160,161]. Moreover, miR-10b, miR-193a, miR-224-452 cluster, miR-182-183-96 cluster, miR148a, miR-23b, and miR-365 were specifically found in the WNT-MB subgroup [162,163]. Overexpression of miR-17-72 cluster (oncomiR) was frequently associated with SHH-MB [164]. Similarly, 12 miRNAs, including miR-181a, miR-135b, and miR-660, were overexpressed in group 4 MB [165].

In group $3 \mathrm{MB}$, loss of heterozygosity at locus $17 \mathrm{p}$ has been reported in $>50 \%$ of group $3 \mathrm{MB}$ cases, recapitulated in a local cohort of MB patients (GSE 148390) [166-172]. Along locus 17p13.3 lie multiple tumor suppressor genes, including three micro-RNAs: miR-22, miR-212, and miR-1253. Aside from being downregulated in medulloblastoma, forced expression of miR-22 in MB cell lines resulted in reduced tumorigenesis by downregulating 3'-phosphoadenosine 5' -phosphosulfate transporters 1 (PAPST1) [159,173]. Similarly, we have uncovered transcriptional silencing of miR-212 via histone modification in group 3 MB [174]. Specifically, in HDMB03 and D425 cells with baseline-reduced miR-212- 
3p expression, we showed enriched methylated H3K27 and high EZH2 activity, which, as discussed prior, are epigenetic markers consistent with a stem/progenitor cell-like identity [127]. Consequently, treatment with pan-HDAC inhibitors or EZH2 silencing returned miR-212 expressions to baseline. Induction of miR-212 within orthotopic tumors led to a significant augmentation of longevity in animal models concurrent with smaller tumor sizes. We also identified an important oncogenic target of miR-212, Nuclear Factor $\mathrm{I} / \mathrm{B}$, a target of c-Myc whose amplification in group 3 tumors is a cardinal high-risk feature [174]. Finally, on the terminal end of this locus lies miR-1253. In studying this micro-RNA, we revealed silencing of miR-1253 via hypermethylation in group 3 and 4 tumors [172]. On top of negatively affecting tumor cell viability, migration/invasion, and colony formation, miR-1253 activated apoptosis and led to cell cycle arrest at the $\mathrm{G}_{0} / \mathrm{G}_{1}$ phase. Oncogenic targets identified included CDK6, a cell cycle checkpoint marker for proliferation overexpressed in group 3 and 4 tumors [22], and CD279 (B7-H3), an immune checkpoint molecule that inhibits T-cell function and facilitates tumor proliferation and invasion [175].

\section{2. $\operatorname{LncRNA}$}

LncRNAs can span over 200 nucleotides in length and are mostly transcribed by RNA polymerase II. Aside from their important role in the transcriptional, post-transcriptional, and epigenetic regulation of gene expression, they can play key roles in cell proliferation, apoptosis, migration, and invasion [176]. Deregulated expression of lncRNAs is associated with tumorigenesis of various cancers, including MB [155,177]. For example, lncRNA TP73-AS1 promoted the survival, migration, and proliferation of MB cells in vitro and in vivo by sequestering miR-494-3p and upregulating EIF5A2 expression [178]. In SHH MB, lncRNA NKX2-AS1 sequestered miR-103, miR-10, and miR-548m, downregulating essential tumor suppressors BTG2/LAST, and contributing to tumorigenesis [179]. LncHLX-2-7 was highly upregulated in group $3 \mathrm{MB}$; silencing its expression significantly suppressed cell growth and induced tumor cellular apoptosis [180]. Linc-NeD125, which is significantly upregulated in group $4 \mathrm{MB}$, sequestered miR-19a-3p, miR-19b-3p, and miR-106a-5p, de-repressing key driver genes CDK6, MYCN, SNCAIP, and KDM6A [181].

Using high-throughput techniques, putative lncRNA signatures have been generated to differentiate medulloblastoma subgroups accurately $[180,182]$. One of these studies validated the top 10 oncogenic or tumor suppressive lncRNAs in each MB subgroup and explored their associated molecular pathways. Among these identified lncRNAs, high expression of HAND2-AS1 in WNT-MB, low expression of MEG3 in SHH-MB, high expression of DLEU2 and DSCR8 in group $3 \mathrm{MB}$, and high expression of DLEU2 and low expression of XIST in group 4 were associated with poor prognosis [183]. In this manner, lncRNAs may be exploited as prognostic biomarkers for molecular identification of MB subgroups.

\subsection{CircRNA}

Circular RNAs (circRNAs) are generated from specific splicing events where the $5^{\prime}$ and $3^{\prime}$ termini are covalently linked [184]. Possessing both tissue-specific and cell-specific expression patterns, they can function as miRNA sponges or protein decoys to influence various biological processes [184]. Their importance to MB pathophysiology is an emerging topic of high interest. Next-generation sequencing has identified 33 differentially expressed circRNAs in MB tissues. Of these, circ-SKA3 and circ-DTL were upregulated, while circCRTAM, circ-MAP3K5, circ-RIMS1-1, and circ-FLT3-1 were significantly downregulated in MB tissues. Downregulation of circ-SKA3 and circ-DTL suppressed MB cell proliferation, migration, and invasion by regulating the expression of host genes [185].

In summary, although the functional significance of the vast majority of ncRNAs remains undefined, mounting evidence on the role of ncRNAs in cancer tumorigenesis suggests a pivotal role in MB pathophysiology. Possessing subgroup specificity, ncRNA 
signatures may be exploited to personalize therapies by acting dually as biomarkers and therapeutic agents.

\section{Future Directions and Conclusions}

Patients with medulloblastoma have been classically stratified into average-risk or high-risk groups [21,41]. More recent genome-based, high-throughput analytic techniques have helped subdivide medulloblastoma into four primary subgroups [100]. Coupling molecular, cytogenetic, and clinical features with methylation profiling and prognostic data has led to an even more refined subgroup classification into 12 subtypes [22]. However, despite advances in diagnostic accuracy, a large prognostic discordance exists between average risk (WNT and SHH) and high-risk (groups 3 and 4) tumors that continue to be treated similarly, widening the survival gap amongst patients [41]. Thus, our primary objective must be to leverage our advanced understanding of key signaling pathways to improve upon and tailor future therapies to the individual patient, capitalizing on the rich diagnostic accuracy we currently possess. Moreover, focus must shift towards slowly eradicating cycling tumor-initiating cells that are resistant to cytotoxic drugs and inhibitors, such as those expressing SOX2 ${ }^{+}$or high $\mathrm{H} 3 \mathrm{~K} 27$ methylation and EZH2 expression, and can eventually give rise to recurrent tumors recalcitrant to treatment. Targeted (individualized) therapies and drug combinations based on genetic and epigenic signatures will likely provide better outcomes with far less adverse effects and might be better tolerated by our youngest patients. Finally, many of the studies described in this review are based primarily on cell culture models that do not recapitulate the complexity of in vivo tumors. Thus, the field would benefit from improved pre-clinical and animal models, especially for group 3 and $4 \mathrm{MB}$, to help advance our understanding of the molecular basis for high-risk disease and to direct our efforts in generating and testing inhibitors that may squelch the gap in survival punctuating high-risk tumor subgroups.

Author Contributions: All authors contributed equally to conceptualization and writing, reviewing, and editing the manuscript. Figures were generated by S.R. and S.M. Tables were generated by S.R., A.R., and S.M. All authors have read and agreed to the published version of the manuscript.

Funding: Research in the laboratory of S.R. is supported by grants from the Edna Ittner Pediatric Fund and the Team Jack Brain Tumor Foundation. Research in the laboratory of K.B. is supported by grants from the National Institutes of Health/National Cancer Institute (R03CA235214) and the Nebraska Department of Health and Human Services (LB506). Research in the laboratory of AR is supported by grants from the National Institute of General Medical Sciences (GM106397), the Nebraska Department of Health (2020-47), and the Fred and Pamela Buffett Cancer Center. Research in the laboratory of S.M. is supported by grants from the National Institutes of Child and Human Development (K12 HD047349-17), the Nebraska Department of Health and Human Services (LB506, LB606), and the Team Jack Brain Tumor Foundation. All labs have received support from the state of Nebraska through the Pediatric Cancer Research Group.

Institutional Review Board Statement: Not applicable.

Informed Consent Statement: Not applicable.

Data Availability Statement: Not applicable.

Acknowledgments: We wanted to acknowledge Deborah Perry for her assistance with obtaining histologic images of each subgroup, shown in Figure 2.

Conflicts of Interest: The authors declare no conflict of interest.

\section{References}

1. Ostrom, Q.T.; Gittleman, H.; Truitt, G.; Boscia, A.; Kruchko, C.; Barnholtz-Sloan, J.S. CBTRUS Statistical Report: Primary Brain and Other Central Nervous System Tumors Diagnosed in the United States in 2011-2015. Neuro-oncology 2018, 20, iv1-iv86. [CrossRef]

2. Massimino, M.; Biassoni, V.; Gandola, L.; Garrè, M.L.; Gatta, G.; Giangaspero, F.; Poggi, G.; Rutkowski, S. Childhood medulloblastoma. Crit. Rev. Oncol./Hematol. 2016, 105, 35-51. [CrossRef] [PubMed] 
3. Northcott, P.A.; Jones, D.T.W.; Kool, M.; Robinson, G.; Gilbertson, R.J.; Cho, Y.-J.; Pomeroy, S.L.; Korshunov, A.; Lichter, P.; Taylor, M.D.; et al. Medulloblastomics: The end of the beginning. Nat. Rev. Cancer 2012, 12, 818-834. [CrossRef]

4. $\quad$ Ostrom, Q.T.; Gittleman, H.; Farah, P.; Ondracek, A.; Chen, Y.; Wolinsky, Y.; Stroup, N.E.; Kruchko, C.; Barnholtz-Sloan, J.S. CBTRUS statistical report: Primary brain and central nervous system tumors diagnosed in the United States in 2006-2010. Neuro. Oncol. 2013, 15 (Suppl. S2), ii1-ii56. [CrossRef] [PubMed]

5. Rossi, A.; Caracciolo, V.; Russo, G.; Reiss, K.; Giordano, A. Medulloblastoma: From molecular pathology to therapy. Clin. Cancer Res. 2008, 14, 971-976. [CrossRef] [PubMed]

6. Smoll, N.R.; Drummond, K.J. The incidence of medulloblastomas and primitive neurectodermal tumours in adults and children. J. Clin. Neurosci. 2012, 19, 1541-1544. [CrossRef] [PubMed]

7. Taylor, M.D.; Northcott, P.A.; Korshunov, A.; Remke, M.; Cho, Y.-J.; Clifford, S.C.; Eberhart, C.G.; Parsons, D.W.; Rutkowski, S.; Gajjar, A.; et al. Molecular subgroups of medulloblastoma: The current consensus. Acta Neuropathol. 2011, 123, 465-472. [CrossRef]

8. Raffel, C. Medulloblastoma: Molecular Genetics and Animal Models. Neoplasia 2004, 6, 310-322. [CrossRef]

9. Ryzhova, M.V.; Zheludkova, O.G.; Kumirova, É.V.; Shishkina, L.V.; Panina, T.N.; Gorelyshev, S.K.; Khukhlaeva, E.A.; Mazerkina, N.A.; Matuev, K.B.; Medvedeva, O.A.; et al. Characteristics of medulloblastoma in children under age of three years. Zhurnal Vopr. Neirokhirurgii Im. N. N. Burd. 2013, 77, 3-10, discussion 11.

10. Louis, D.N.; Perry, A.; Reifenberger, G.; von Deimling, A.; Figarella-Branger, D.; Cavenee, W.K.; Ohgaki, H.; Wiestler, O.D.; Kleihues, P.; Ellison, D.W. The 2016 World Health Organization Classification of Tumors of the Central Nervous System: A summary. Acta Neuropathol. 2016, 131, 803-820. [CrossRef]

11. Fattet, S.; Haberler, C.; Legoix, P.; Varlet, P.; Lellouch-Tubiana, A.; Lair, S.; Manie, E.; Raquin, M.-A.; Bours, D.; Carpentier, S.; et al. Beta-catenin status in paediatric medulloblastomas: Correlation of immunohistochemical expression with mutational status, genetic profiles, and clinical characteristics. J. Pathol. 2009, 218, 86-94. [CrossRef]

12. Hovestadt, V.; Jones, D.T.W.; Picelli, S.; Wang, W.; Kool, M.; Northcott, P.A.; Sultan, M.; Stachurski, K.; Ryzhova, M.; Warnatz, H.-J.; et al. Decoding the regulatory landscape of medulloblastoma using DNA methylation sequencing. Nature 2014, 510, 537-541. [CrossRef]

13. Kool, M.; Korshunov, A.; Remke, M.; Jones, D.T.; Schlanstein, M.; Northcott, P.A.; Cho, Y.-J.; Koster, J.; Schouten-van Meeteren, A.; Van Vuurden, D.; et al. Molecular subgroups of medulloblastoma: An international meta-analysis of transcriptome, genetic aberrations, and clinical data of WNT, SHH, Group 3, and Group 4 medulloblastomas. Acta Neuropathol. 2012, 123, $473-484$. [CrossRef]

14. Kool, M.; Koster, J.; Bunt, J.; Hasselt, N.E.; Lakeman, A.; Van Sluis, P.; Troost, D.; Meeteren, N.S.-V.; Caron, H.N.; Cloos, J.; et al. Integrated Genomics Identifies Five Medulloblastoma Subtypes with Distinct Genetic Profiles, Pathway Signatures and Clinicopathological Features. PLoS ONE 2008, 3, e3088. [CrossRef]

15. Korshunov, A.; Remke, M.; Kool, M.; Hielscher, T.; Northcott, P.A.; Williamson, D.; Pfaff, E.; Witt, H.; Jones, D.T.W.; Ryzhova, M.; et al. Biological and clinical heterogeneity of MYCN-amplified medulloblastoma. Acta Neuropathol. 2011, 123, 515-527. [CrossRef]

16. Northcott, P.A.; Shih, D.J.H.; Peacock, J.; Garzia, L.; Morrissy, A.S.; Zichner, T.; Stütz, A.M.; Korshunov, A.; Reimand, J.; Schumacher, S.E.; et al. Subgroup-specific structural variation across 1000 medulloblastoma genomes. Nature 2012, 488, 49-56. [CrossRef]

17. Park, A.K.; Lee, S.-J.; Phi, J.H.; Wang, K.-C.; Kim, D.G.; Cho, B.-K.; Haberler, C.; Fattet, S.; Dufour, C.; Puget, S.; et al. Prognostic classification of pediatric medulloblastoma based on chromosome 17p loss, expression of MYCC and MYCN, and Wnt pathway activation. Neuro-oncology 2011, 14, 203-214. [CrossRef] [PubMed]

18. Remke, M.; Hielscher, T.; Korshunov, A.; Northcott, P.A.; Bender, S.; Kool, M.; Westermann, F.; Benner, A.; Cin, H.; Ryzhova, M.; et al. FSTL5 is a marker of poor prognosis in non-WNT/non-SHH medulloblastoma. J. Clin. Oncol. 2011, 29, 3852-3861. [CrossRef] [PubMed]

19. Robinson, G.; Parker, M.; Kranenburg, T.; Lu, C.; Chen, X.; Ding, L.; Phoenix, T.N.; Hedlund, E.; Wei, L.; Zhu, X.; et al. Novel mutations target distinct subgroups of medulloblastoma. Nature 2012, 488, 43-48. [CrossRef] [PubMed]

20. Wang, X.; Dubuc, A.M.; Ramaswamy, V.; Mack, S.C.; Gendoo, D.; Remke, M.; Wu, X.; Garzia, L.; Luu, B.; Cavalli, F.; et al. Medulloblastoma subgroups remain stable across primary and metastatic compartments. Acta Neuropathol. 2015, 129, 449-457. [CrossRef] [PubMed]

21. Gottardo, N.G.; Hansford, J.R.; McGlade, J.P.; Alvaro, F.; Ashley, D.M.; Bailey, S.; Baker, D.L.; Bourdeaut, F.; Cho, Y.J.; Clay, M.; et al. Medulloblastoma Down Under 2013: A report from the third annual meeting of the International Medulloblastoma Working Group. Acta Neuropathol. 2014, 127, 189-201. [CrossRef]

22. Cavalli, F.M.; Remke, M.; Rampasek, L.; Peacock, J.; Shih, D.J.H.; Luu, B.; Garzia, L.; Torchia, J.; Nor, C.; Morrissy, S.; et al Intertumoral Heterogeneity within Medulloblastoma Subgroups. Cancer Cell 2017, 31, 737-754.e6. [CrossRef] [PubMed]

23. Ramaswamy, V.; Taylor, M.D. Medulloblastoma: From Myth to Molecular. J. Clin. Oncol. 2017, 35, 2355-2363. [CrossRef] [PubMed]

24. Gajjar, A.; Chintagumpala, M.; Ashley, D.; Kellie, S.; Kun, L.E.; Merchant, T.E.; Woo, S.; Wheeler, G.; Ahern, V.; Krasin, M.J.; et al. Risk-adapted craniospinal radiotherapy followed by high-dose chemotherapy and stem-cell rescue in children with newly diagnosed medulloblastoma (St Jude Medulloblastoma-96): Long-term results from a prospective, multicentre trial. Lancet Oncol. 2006, 7, 813-820. [CrossRef] 
25. Packer, R.J.; Gajjar, A.; Vezina, G.; Rorke-Adams, L.; Burger, P.C.; Robertson, P.L.; Bayer, L.; LaFond, D.; Donahue, B.R.; Marymont, M.H.; et al. Phase III Study of Craniospinal Radiation Therapy Followed by Adjuvant Chemotherapy for Newly Diagnosed Average-Risk Medulloblastoma. J. Clin. Oncol. 2006, 24, 4202-4208. [CrossRef] [PubMed]

26. Strother, D.; Lafay-Cousin, L. Adjuvant therapy for high-risk medulloblastoma: More is better? Neuro-oncology 2021, 23, 1048-1049. [CrossRef] [PubMed]

27. Gajjar, A.; Robinson, G.W.; Smith, K.S.; Lin, T.; Merchant, T.E.; Chintagumpala, M.; Mahajan, A.; Su, J.; Bouffet, E.; Bartels, U.; et al. Outcomes by Clinical and Molecular Features in Children With Medulloblastoma Treated With Risk-Adapted Therapy: Results of an International Phase III Trial (SJMB03). J. Clin. Oncol. 2021, 39, 822-835. [CrossRef]

28. Dufour, C.; Foulon, S.; Geoffray, A.; Masliah-Planchon, J.; Figarella-Branger, D.; Bernier-Chastagner, V.; Padovani, L.; GuerriniRousseau, L.; Faure-Conter, C.; Icher, C.; et al. Prognostic relevance of clinical and molecular risk factors in children with high-risk medulloblastoma treated in the phase II trial PNET HR+5. Neuro-oncology 2020, 23, 1163-1172. [CrossRef]

29. Leary, S.E.S.; Packer, R.J.; Li, Y.; Billups, C.A.; Smith, K.S.; Jaju, A.; Heier, L.; Burger, P.; Walsh, K.; Han, Y.; et al. Efficacy of Carboplatin and Isotretinoin in Children With High-risk Medulloblastoma: A Randomized Clinical Trial From the Children's Oncology Group. JAMA Oncol. 2021, 7, 1313-1321. [CrossRef] [PubMed]

30. Tarbell, N.J.; Friedman, H.; Polkinghorn, W.R.; Yock, T.; Zhou, T.; Chen, Z.; Burger, P.; Barnes, P.; Kun, L. High-Risk Medulloblastoma: A Pediatric Oncology Group Randomized Trial of Chemotherapy Before or After Radiation Therapy (POG 9031). J. Clin. Oncol. 2013, 31, 2936-2941. [CrossRef]

31. Lafay-Cousin, L.; Smith, A.; Chi, S.N.; Wells, E.; Madden, J.; Margol, A.; Ramaswamy, V.; Finlay, J.; Taylor, M.D.; Dhall, G.; et al. Clinical, Pathological, and Molecular Characterization of Infant Medulloblastomas Treated with Sequential High-Dose Chemotherapy. Pediatr. Blood Cancer 2016, 63, 1527-1534. [CrossRef]

32. Rutkowski, S.; Bode, U.; Deinlein, F.; Ottensmeier, H.; Warmuth-Metz, M.; Soerensen, N.; Graf, N.; Emser, A.; Pietsch, T.; Wolff, J.E.; et al. Treatment of Early Childhood Medulloblastoma by Postoperative Chemotherapy Alone. N. Engl. J. Med. 2005, 352, 978-986. [CrossRef] [PubMed]

33. Cohen, B.H.; Geyer, J.R.; Miller, D.C.; Curran, J.G.; Zhou, T.; Holmes, E.; Ingles, S.A.; Dunkel, I.J.; Hilden, J.; Packer, R.J.; et al. Pilot Study of Intensive Chemotherapy With Peripheral Hematopoietic Cell Support for Children Less Than 3 Years of Age With Malignant Brain Tumors, the CCG-99703 Phase I/II Study. A Report from the Children's Oncology Group. Pediatr. Neurol. 2015, 53, 31-46. [CrossRef] [PubMed]

34. Lafay-Cousin, L.; Bouffet, E.; Hawkins, C.; Amid, A.; Huang, A.; Mabbott, D.J. Impact of Radiation Avoidance on Survival and Neurocognitive Outcome in Infant Medulloblastoma. Curr. Oncol. 2009, 16, 21-28. [CrossRef] [PubMed]

35. Geyer, J.R.; Sposto, R.; Jennings, M.; Boyett, J.M.; Axtell, R.A.; Breiger, D.; Broxson, E.; Donahue, B.; Finlay, J.L.; Goldwein, J.W.; et al. Multiagent chemotherapy and deferred radiotherapy in infants with malignant brain tumors: A report from the Children's Cancer Group. J. Clin. Oncol. 2005, 23, 7621-7631. [CrossRef] [PubMed]

36. Grill, J.; Sainte-Rose, C.; Jouvet, A.; Gentet, J.-C.; Lejars, O.; Frappaz, D.; Doz, F.; Rialland, X.; Pichon, F.; Bertozzi, A.-I.; et al. Treatment of medulloblastoma with postoperative chemotherapy alone: An SFOP prospective trial in young children. Lancet Oncol. 2005, 6, 573-580. [CrossRef]

37. Min, H.S.; Lee, J.Y.; Kim, S.-K.; Park, S.-H. Genetic Grouping of Medulloblastomas by Representative Markers in Pathologic Diagnosis. Transl. Oncol. 2013, 6, 265-272. [CrossRef]

38. Juraschka, K.; Taylor, M.D. Medulloblastoma in the age of molecular subgroups: A review. J. Neurosurg. Pediatr. 2019, 24, 353-363. [CrossRef]

39. Gibson, P.; Tong, Y.; Robinson, G.; Thompson, M.C.; Currle, D.S.; Eden, C.; Kranenburg, T.; Hogg, T.; Poppleton, H.; Martin, J.; et al. Subtypes of medulloblastoma have distinct developmental origins. Nature 2010, 468, 1095-1099. [CrossRef]

40. Ellison, D.W.; Dalton, J.; Kocak, M.; Nicholson, S.L.; Fraga, C.; Neale, G.; Kenney, A.M.; Brat, D.J.; Perry, A.; Yong, W.H.; et al. Medulloblastoma: Clinicopathological correlates of SHH, WNT, and non-SHH/WNT molecular subgroups. Acta Neuropathol. 2011, 121, 381-396. [CrossRef]

41. Gilbertson, R.J. Medulloblastoma: Signalling a change in treatment. Lancet Oncol. 2004, 5, 209-218. [CrossRef]

42. Wechsler-Reya, R.; Scott, M.P. The Developmental Biology of Brain Tumors. Annu. Rev. Neurosci. 2001, 24, 385-428. [CrossRef]

43. Geron, L.; Salomao, K.B.; Borges, K.S.; Andrade, A.F.; Corrêa, C.A.; Scrideli, C.A.; Tone, L.G. Molecular characterization of Wnt pathway and function of beta-catenin overexpression in medulloblastoma cell lines. Cytotechnology 2018, 70, 1713-1722. [CrossRef]

44. Dale, T.C. Signal transduction by the Wnt family of ligands. Biochem. J. 1998, 329 Pt 2, 209-223. [CrossRef] [PubMed]

45. Kang, D.E.; Soriano, S.; Xia, X.; Eberhart, C.G.; De Strooper, B.; Zheng, H.; Koo, E.H. Presenilin couples the paired phosphorylation of beta-catenin independent of axin: Implications for beta-catenin activation in tumorigenesis. Cell 2002, 110, 751-762. [CrossRef]

46. Rogers, H.A.; Miller, S.; Lowe, J.; Brundler, M.-A.; Coyle, B.; Grundy, R.G. An investigation of WNT pathway activation and association with survival in central nervous system primitive neuroectodermal tumours (CNS PNET). Br. J. Cancer 2009, 100, 1292-1302. [CrossRef] [PubMed]

47. Koch, A.; Waha, A.; Berthold, F.; Wolter, M.; Reifenberger, J.; Hartmann, W.; Friedl, W.; Reifenberger, G.; Wiestler, O.D.; Pietsch, T. Somatic mutations ofWNT/wingless signaling pathway components in primitive neuroectodermal tumors. Int. J. Cancer 2001, 93, 445-449. [CrossRef] [PubMed] 
48. Zurawel, R.H.; Chiappa, S.A.; Allen, C.; Raffel, C. Sporadic medulloblastomas contain oncogenic beta-catenin mutations. Cancer Res. 1998, 58, 896-899.

49. Gilbertson, R.J.; Ellison, D.W. The Origins of Medulloblastoma Subtypes. Annu. Rev. Pathol. Mech. Dis. 2008, 3, 341-365. [CrossRef]

50. Baryawno, N.; Sveinbjornsson, B.; Eksborg, S.; Chen, C.S.; Kogner, P.; Johnsen, J.I. Small-molecule inhibitors of phosphatidylinositol 3-kinase/Akt signaling inhibit Wnt/beta-catenin pathway cross-talk and suppress medulloblastoma growth. Cancer Res. 2010, 70, 266-276. [CrossRef]

51. Ye, Z.-N.; Yu, M.-Y.; Kong, L.-M.; Wang, W.-H.; Yang, Y.-F.; Liu, J.-Q.; Qiu, M.-H.; Li, Y. Biflavone Ginkgetin, a Novel Wnt Inhibitor, Suppresses the Growth of Medulloblastoma. Nat. Prod. Bioprospecting 2015, 5, 91-97. [CrossRef]

52. He, M.; Li, Y.; Zhang, L.; Li, L.; Shen, Y.; Lin, L.; Zheng, W.; Chen, L.; Bian, X.; Ng, H.K.; et al. Curcumin suppresses cell proliferation through inhibition of the Wnt/beta-catenin signaling pathway in medulloblastoma. Oncol. Rep. 2014, 32, 173-180. [CrossRef]

53. Yang, J.; Wu, J.; Tan, C.; Klein, P.S. PP2A:B56epsilon is required for Wnt/beta-catenin signaling during embryonic development. Development 2003, 130, 5569-5578. [CrossRef]

54. Cimmino, F.; Scoppettuolo, M.N.; Carotenuto, M.; De Antonellis, P.; Di Dato, V.; De Vita, G.; Zollo, M. Norcantharidin impairs medulloblastoma growth by inhibition of Wnt/beta-catenin signaling. J. Neuro-oncol. 2012, 106, 59-70. [CrossRef]

55. Ris, M.D.; Packer, R.; Goldwein, J.; Jones-Wallace, D.; Boyett, J.M. Intellectual Outcome After Reduced-Dose Radiation Therapy Plus Adjuvant Chemotherapy for Medulloblastoma: A Children's Cancer Group Study. J. Clin. Oncol. 2001, 19, 3470-3476. [CrossRef]

56. Leary, S.E.; Olson, J.M. The molecular classification of medulloblastoma: Driving the next generation clinical trials. Curr. Opin. Pediatr. 2012, 24, 33-39. [CrossRef]

57. Thompson, E.M.; Ashley, D.; Landi, D. Current medulloblastoma subgroup specific clinical trials. Transl. Pediatr. 2020, 9, 157-162. [CrossRef] [PubMed]

58. Olmeda, D.; Castel, S.; Vilaro, S.; Cano, A. Beta-catenin regulation during the cell cycle: Implications in G2/M and apoptosis. Mol. Biol. Cell 2003, 14, 2844-2860. [CrossRef] [PubMed]

59. Hadjihannas, M.V.; Bernkopf, D.B.; Bruckner, M.; Behrens, J. Cell cycle control of Wnt/beta-catenin signalling by conductin/axin2 through CDC20. EMBO Rep. 2012, 13, 347-354. [CrossRef] [PubMed]

60. Poschl, J.; Bartels, M.; Ohli, J.; Bianchi, E.; Kuteykin-Teplyakov, K.; Grammel, D.; Ahlfeld, J.; Schüller, U. Wnt/beta-catenin signaling inhibits the Shh pathway and impairs tumor growth in Shh-dependent medulloblastoma. Acta Neuropathol. 2014, 127, 605-607. [CrossRef]

61. Manoranjan, B.; Venugopal, C.; Bakhshinyan, D.; Adile, A.A.; Richards, L.; Kameda-Smith, M.M.; Whitley, O.; Dvorkin-Gheva, A.; Subapanditha, M.; Savage, N.; et al. Wnt activation as a therapeutic strategy in medulloblastoma. Nat. Commun. 2020, 11, 4323. [CrossRef] [PubMed]

62. Northcott, P.A.; Buchhalter, I.; Morrissy, A.S.; Hovestadt, V.; Weischenfeldt, J.; Ehrenberger, T.; Gröbner, S.; Segura-Wang, M.; Zichner, T.; Rudneva, V.A.; et al. The whole-genome landscape of medulloblastoma subtypes. Nature 2017, 547, 311-317. [CrossRef]

63. Kool, M.; Jones, D.T.W.; Jaeger, N.; Northcott, P.A.; Pugh, T.J.; Hovestadt, V.; Piro, R.M.; Esparza, L.A.; Markant, S.L.; Remke, M.; et al. Genome Sequencing of SHH Medulloblastoma Predicts Genotype-Related Response to Smoothened Inhibition. Cancer Cell 2014, 25, 393-405. [CrossRef]

64. Hartmann, W.; Digon-Söntgerath, B.; Koch, A.; Waha, A.; Endl, E.; Dani, I.; Denkhaus, D.; Goodyer, C.G.; Sörensen, N.; Wiestler, O.D.; et al. Phosphatidylinositol 3'-Kinase/AKT Signaling Is Activated in Medulloblastoma Cell Proliferation and Is Associated with Reduced Expression ofPTEN. Clin. Cancer Res. 2006, 12, 3019-3027. [CrossRef]

65. Eckerdt, F.; Clymer, J.; Bell, J.B.; Beauchamp, E.M.; Blyth, G.T.; Goldman, S.; Platanias, L.C. Pharmacological mTOR targeting enhances the antineoplastic effects of selective PI3Kalpha inhibition in medulloblastoma. Sci. Rep. 2019, 9, 12822. [CrossRef]

66. Zhukova, N.; Ramaswamy, V.; Remke, M.; Pfaff, E.; Shih, D.J.; Martin, D.C.; Castelo-Branco, P.; Baskin, B.; Ray, P.N.; Bouffet, E.; et al. Subgroup-specific prognostic implications of TP53 mutation in medulloblastoma. J. Clin. Oncol. 2013, 31, 2927-2935. [CrossRef] [PubMed]

67. Robinson, G.W.; Rudneva, V.; Buchhalter, I.; Billups, C.A.; Waszak, S.; Smith, K.S.; Bowers, D.; Bendel, A.; Fisher, P.; Partap, S.; et al. Risk-adapted therapy for young children with medulloblastoma (SJYC07): Therapeutic and molecular outcomes from a multicentre, phase 2 trial. Lancet Oncol. 2018, 19, 768-784. [CrossRef]

68. Menyhárt, O.; Győrffy, B. Molecular stratifications, biomarker candidates and new therapeutic options in current medulloblastoma treatment approaches. Cancer Metastasis Rev. 2020, 39, 211-233. [CrossRef]

69. Li, Y.; Song, Q.; Day, B.W. Phase I and phase II sonidegib and vismodegib clinical trials for the treatment of paediatric and adult MB patients: A systemic review and meta-analysis. Acta Neuropathol. Commun. 2019, 7, 123-128. [CrossRef] [PubMed]

70. Robinson, G.W.; Orr, B.A.; Wu, G.; Gururangan, S.; Lin, T.; Qaddoumi, I.; Packer, R.J.; Goldman, S.; Prados, M.D.; Desjardins, A.; et al. Vismodegib Exerts Targeted Efficacy Against Recurrent Sonic Hedgehog-Subgroup Medulloblastoma: Results From Phase II Pediatric Brain Tumor Consortium Studies PBTC-025B and PBTC-032. J. Clin. Oncol. 2015, 33, 2646-2654. [CrossRef] 
71. Petrirena, G.J.; Masliah-Planchon, J.; Sala, Q.; Pourroy, B.; Frappaz, D.; Tabouret, E.; Graillon, T.; Gentet, J.-C.; Delattre, O.; Chinot, O.; et al. Recurrent extraneural sonic hedgehog medulloblastoma exhibiting sustained response to vismodegib and temozolomide monotherapies and inter-metastatic molecular heterogeneity at progression. Oncotarget 2018, 9, 10175-10183. [CrossRef] [PubMed]

72. Yauch, R.L.; Dijkgraaf, G.J.P.; Alicke, B.; Januario, T.; Ahn, C.P.; Holcomb, T.; Pujara, K.; Stinson, J.; Callahan, C.A.; Tang, T.; et al. Smoothened Mutation Confers Resistance to a Hedgehog Pathway Inhibitor in Medulloblastoma. Science 2009, 326, 572-574. [CrossRef] [PubMed]

73. Sharpe, H.J.; Pau, G.; Dijkgraaf, G.J.; Basset-Seguin, N.; Modrusan, Z.; Januario, T.; Tsui, V.; Durham, A.B.; Dlugosz, A.A.; Haverty, P.M.; et al. Genomic Analysis of Smoothened Inhibitor Resistance in Basal Cell Carcinoma. Cancer Cell 2015, $27,327-341$. [CrossRef]

74. Danial, C.; Sarin, K.Y.; Oro, A.E.; Chang, A.L.S. An Investigator-Initiated Open-Label Trial of Sonidegib in Advanced Basal Cell Carcinoma Patients Resistant to Vismodegib. Clin. Cancer Res. 2015, 22, 1325-1329. [CrossRef] [PubMed]

75. Li, Q.-R.; Zhao, H.; Zhang, X.-S.; Lang, H.; Yu, K. Novel-smoothened inhibitors for therapeutic targeting of naïve and drugresistant hedgehog pathway-driven cancers. Acta Pharmacol. Sin. 2018, 40, 257-267. [CrossRef]

76. Kumar, V.; Chaudhary, A.K.; Dong, Y.; Zhong, H.A.; Mondal, G.; Lin, F.; Kumar, V.; Mahato, R.I. Design, Synthesis and Biological Evaluation of novel Hedgehog Inhibitors for treating Pancreatic Cancer. Sci. Rep. 2017, 7, 1665. [CrossRef]

77. Robinson, G.W.; Kaste, S.C.; Chemaitilly, W.; Bowers, D.; Laughton, S.; Smith, A.; Gottardo, N.; Partap, S.; Bendel, A.; Wright, K.D.; et al. Irreversible growth plate fusions in children with medulloblastoma treated with a targeted hedgehog pathway inhibitor. Oncotarget 2017, 8, 69295-69302. [CrossRef]

78. Ocasio, J.; Babcock, B.; Malawsky, D.; Weir, S.J.; Loo, L.; Simon, J.M.; Zylka, M.J.; Hwang, D.; Dismuke, T.; Sokolsky, M.; et al. scRNA-seq in medulloblastoma shows cellular heterogeneity and lineage expansion support resistance to SHH inhibitor therapy. Nat. Commun. 2019, 10, 5829. [CrossRef]

79. Vanner, R.J.; Remke, M.; Gallo, M.; Selvadurai, H.J.; Coutinho, F.; Lee, L.; Kushida, M.; Head, R.; Morrissy, S.; Zhu, X.; et al. Quiescent Sox2+ Cells Drive Hierarchical Growth and Relapse in Sonic Hedgehog Subgroup Medulloblastoma. Cancer Cell 2014, 26, 33-47. [CrossRef]

80. Ahlfeld, J.; Favaro, R.; Pagella, P.; Kretzschmar, H.A.; Nicolis, S.; Schüller, U. Sox2 Requirement in Sonic Hedgehog-Associated Medulloblastoma. Cancer Res. 2013, 73, 3796-3807. [CrossRef] [PubMed]

81. Selvadurai, H.J.; Luis, E.; Desai, K.; Lan, X.; Vladoiu, M.C.; Whitley, O.; Galvin, C.; Vanner, R.J.; Lee, L.; Whetstone, H.; et al. Medulloblastoma Arises from the Persistence of a Rare and Transient Sox2+ Granule Neuron Precursor. Cell Rep. 2020, $31,107511$. [CrossRef] [PubMed]

82. Hagey, D.; Klum, S.; Kurtsdotter, I.; Zaouter, C.; Topcic, D.; Andersson, O.; Bergsland, M.; Muhr, J. SOX2 regulates common and specific stem cell features in the CNS and endoderm derived organs. PLoS Genet. 2018, 14, e1007224. [CrossRef]

83. Hagey, D.; Muhr, J. Sox2 Acts in a Dose-Dependent Fashion to Regulate Proliferation of Cortical Progenitors. Cell Rep. 2014, 9 , 1908-1920. [CrossRef]

84. Metz, E.P.; Rizzino, A. Sox2 dosage: A critical determinant in the functions of Sox2 in both normal and tumor cells. J. Cell. Physiol. 2019, 234, 19298-19306. [CrossRef] [PubMed]

85. Cox, J.L.; Wilder, P.J.; Desler, M.; Rizzino, A. Elevating SOX2 Levels Deleteriously Affects the Growth of Medulloblastoma and Glioblastoma Cells. PLoS ONE 2012, 7, e44087. [CrossRef]

86. Wuebben, E.L.; Wilder, P.J.; Cox, J.L.; Grunkemeyer, J.A.; Caffrey, T.; Hollingsworth, M.A.; Rizzino, A. SOX2 functions as a molecular rheostat to control the growth, tumorigenicity and drug responses of pancreatic ductal adenocarcinoma cells. Oncotarget 2016, 7, 34890-34906. [CrossRef]

87. Metz, E.P.; Wilder, P.J.; Dong, J.; Datta, K.; Rizzino, A. Elevating SOX2 in prostate tumor cells upregulates expression of neuroendocrine genes, but does not reduce the inhibitory effects of enzalutamide. J. Cell. Physiol. 2019, 235, 3731-3740. [CrossRef] [PubMed]

88. Metz, E.P.; Wuebben, E.L.; Wilder, P.J.; Cox, J.L.; Datta, K.; Coulter, D.; Rizzino, A. Tumor quiescence: Elevating SOX2 in diverse tumor cell types downregulates a broad spectrum of the cell cycle machinery and inhibits tumor growth. BMC Cancer 2020, 20, 941. [CrossRef]

89. Shih, D.J.; Northcott, P.A.; Remke, M.; Korshunov, A.; Ramaswamy, V.; Kool, M.; Luu, B.; Yao, Y.; Wang, X.; Dubuc, A.M.; et al. Cytogenetic prognostication within medulloblastoma subgroups. J. Clin. Oncol. 2014, 32, 886-896. [CrossRef] [PubMed]

90. Lospinoso Severini, L.; Ghirga, F.; Bufalieri, F.; Quaglio, D.; Infante, P.; Di Marcotullio, L. The SHH/GLI signaling pathway: A therapeutic target for medulloblastoma. Expert Opin. Ther. Targets 2020, 24, 1159-1181. [CrossRef]

91. Vladoiu, M.C.; El-Hamamy, I.; Donovan, L.K.; Farooq, H.; Holgado, B.L.; Sundaravadanam, Y.; Ramaswamy, V.; Hendrikse, L.; Kumar, S.; Mack, S.C.; et al. Childhood cerebellar tumours mirror conserved fetal transcriptional programs. Nature 2019, 572, 67-73. [CrossRef]

92. Perreault, S.; Ramaswamy, V.; Achrol, A.; Chao, K.; Liu, T.; Shih, D.; Remke, M.; Schubert, S.; Bouffet, E.; Fisher, P.; et al. MRI Surrogates for Molecular Subgroups of Medulloblastoma. Am. J. Neuroradiol. 2014, 35, 1263-1269. [CrossRef]

93. Cho, Y.-J.; Tsherniak, A.; Tamayo, P.; Santagata, S.; Ligon, A.; Greulich, H.; Berhoukim, R.; Amani, V.; Goumnerova, L.; Eberhart, C.G.; et al. Integrative Genomic Analysis of Medulloblastoma Identifies a Molecular Subgroup That Drives Poor Clinical Outcome. J. Clin. Oncol. 2011, 29, 1424-1430. [CrossRef] [PubMed] 
94. Thompson, E.M.; Hielscher, T.; Bouffet, E.; Remke, M.; Luu, B.; Gururangan, S.; McLendon, R.E.; Bigner, D.D.; Lipp, E.S.; Perreault, S.; et al. Prognostic value of medulloblastoma extent of resection after accounting for molecular subgroup: A retrospective integrated clinical and molecular analysis. Lancet Oncol. 2016, 17, 484-495. [CrossRef]

95. Huang, G.; Xu, Q.; Cui, Y.; Li, N.; Bian, X.; Lv, S. Medulloblastoma stem cells: Promising targets in medulloblastoma therapy. Cancer Sci. 2016, 107, 583-589. [CrossRef]

96. Northcott, P.A.; Lee, C.; Zichner, T.; Stütz, A.M.; Erkek, S.; Kawauchi, D.; Shih, D.J.H.; Hovestadt, V.; Zapatka, M.; Sturm, D.; et al. Enhancer hijacking activates GFI1 family oncogenes in medulloblastoma. Nature 2014, 511, 428-434. [CrossRef]

97. Menyhárt, O.; Giangaspero, F.; Győrffy, B. Molecular markers and potential therapeutic targets in non-WNT/non-SHH (group 3 and group 4) medulloblastomas. J. Hematol. Oncol. 2019, 12, 29. [CrossRef]

98. Jones, D.T.W.; Jaeger, N.; Kool, M.; Zichner, T.; Hutter, B.; Sultan, M.; Cho, Y.-J.; Pugh, T.; Hovestadt, V.; Stütz, A.M.; et al. Dissecting the genomic complexity underlying medulloblastoma. Nature 2012, 488, 100-105. [CrossRef] [PubMed]

99. Schwalbe, E.; Lindsey, J.C.; Nakjang, S.; Crosier, S.; Smith, A.J.; Hicks, D.; Rafiee, G.; Hill, R.M.; Iliasova, A.; Stone, T.; et al. Novel molecular subgroups for clinical classification and outcome prediction in childhood medulloblastoma: A cohort study. Lancet Oncol. 2017, 18, 958-971. [CrossRef]

100. Ramaswamy, V.; Remke, M.; Bouffet, E.; Bailey, S.; Clifford, S.C.; Doz, F.; Kool, M.; Dufour, C.; Vassal, G.; Milde, T.; et al. Risk stratification of childhood medulloblastoma in the molecular era: The current consensus. Acta Neuropathol. 2016, 131, 821-831. [CrossRef] [PubMed]

101. Bautista, F.; Fioravantti, V.; de Rojas, T.; Carceller, F.; Madero, L.; Lassaletta, A.; Moreno, L. Medulloblastoma in children and adolescents: A systematic review of contemporary phase I and II clinical trials and biology update. Cancer Med. 2017, 6, 2606-2624. [CrossRef] [PubMed]

102. Ueno, M.; Chiba, Y.; Murakami, R.; Matsumoto, K.; Kawauchi, M.; Fujihara, R. Blood-brain barrier and blood-cerebrospinal fluid barrier in normal and pathological conditions. Brain Tumor Pathol. 2016, 33, 89-96. [CrossRef] [PubMed]

103. Voskamp, M.J.; Li, S.; van Daalen, K.R.; Crnko, S.; Broeke, T.T.; Bovenschen, N. Immunotherapy in Medulloblastoma: Current State of Research, Challenges, and Future Perspectives. Cancers 2021, 13, 5387. [CrossRef]

104. Pei, Y.; Moore, C.E.; Wang, J.; Tewari, A.K.; Eroshkin, A.; Cho, Y.-J.; Witt, H.; Korshunov, A.; Read, T.-A.; Sun, J.L.; et al. An Animal Model of MYC-Driven Medulloblastoma. Cancer Cell 2012, 21, 155-167. [CrossRef] [PubMed]

105. Kawauchi, D.; Robinson, G.; Uziel, T.; Gibson, P.; Rehg, J.; Gao, C.; Finkelstein, D.; Qu, C.; Pounds, S.; Ellison, D.W.; et al. A Mouse Model of the Most Aggressive Subgroup of Human Medulloblastoma. Cancer Cell 2012, 21, 168-180. [CrossRef]

106. Hill, R.M.; Kuijper, S.; Lindsey, J.; Petrie, K.; Schwalbe, E.; Barker, K.; Boult, J.K.; Williamson, D.; Ahmad, Z.; Hallsworth, A.; et al. Combined MYC and P53 Defects Emerge at Medulloblastoma Relapse and Define Rapidly Progressive, Therapeutically Targetable Disease. Cancer Cell 2014, 27, 72-84. [CrossRef]

107. Pei, Y.; Liu, K.-W.; Wang, J.; Garancher, A.; Tao, R.; Esparza, L.A.; Maier, D.L.; Udaka, Y.T.; Murad, N.; Morrissy, S.; et al. HDAC and PI3K Antagonists Cooperate to Inhibit Growth of MYC- Driven Medulloblastoma. Cancer Cell 2016, 29, 311-323. [CrossRef]

108. Hanaford, A.R.; Archer, T.C.; Price, A.; Kahlert, U.; Maciaczyk, J.; Nikkhah, G.; Kim, J.W.; Ehrenberger, T.; Clemons, P.A.; Dančík, V.; et al. DiSCoVERing innovative therapies for rare tumors: Combining genetically accurate disease models with in silico analysis to identify novel therapeutic targets. Clin. Cancer Res. 2016, 22, 3903-3914. [CrossRef]

109. Tao, R.; Murad, N.; Xu, Z.; Zhang, P.; Okonechnikov, K.; Kool, M.; Hinojosa, S.R.; Lazarski, C.; Zheng, P.; Liu, Y.; et al. MYC Drives Group 3 Medulloblastoma through Transformation of Sox2+ Astrocyte Progenitor Cells. Cancer Res. 2019, 79, 1967-1980. [CrossRef]

110. Delmore, J.E.; Issa, G.C.; Lemieux, M.; Rahl, P.B.; Shi, J.; Jacobs, H.M.; Kastritis, E.; Gilpatrick, T.; Paranal, R.M.; Qi, J.; et al. BET Bromodomain Inhibition as a Therapeutic Strategy to Target c-Myc. Cell 2011, 146, 904-917. [CrossRef] [PubMed]

111. Bandopadhayay, P.; Bergthold, G.; Nguyen, B.; Schubert, S.; Gholamin, S.; Tang, Y.; Bolin, S.; Schumacher, S.E.; Zeid, R.; Masoud, S.; et al. BET bromodomain inhibition of MYC-amplified medulloblastoma. Clin. Cancer Res. 2014, 20, 912-925. [CrossRef]

112. Bolin, S.; Borgenvik, A.; Persson, C.U.; Sundström, A.; Qi, J.; Bradner, J.E.; Weiss, W.A.; Cho, Y.-J.; Weishaupt, H.; Swartling, F.J. Combined BET bromodomain and CDK2 inhibition in MYC-driven medulloblastoma. Oncogene 2018, 37, 2850-2862. [CrossRef]

113. Chaturvedi, N.K.; Kling, M.J.; Griggs, C.N.; Kesherwani, V.; Shukla, M.; McIntyre, E.M.; Ray, S.; Liu, Y.; McGuire, T.R.; Sharp, J.G.; et al. A Novel Combination Approach Targeting an Enhanced Protein Synthesis Pathway in MYC-driven (Group 3) Medulloblastoma. Mol. Cancer Ther. 2020, 19, 1351-1362. [CrossRef]

114. Morfouace, M.; Shelat, A.; Jacus, M.; Freeman, B.B.; Turner, D.; Robinson, S.; Zindy, F.; Wang, Y.-D.; Finkelstein, D.; Ayrault, O.; et al. Pemetrexed and Gemcitabine as Combination Therapy for the Treatment of Group3 Medulloblastoma. Cancer Cell 2014, 25, 516-529. [CrossRef] [PubMed]

115. Thompson, E.M.; Keir, S.T.; Venkatraman, T.; Lascola, C.; Yeom, K.W.; Nixon, A.B.; Liu, Y.; Picard, D.; Remke, M.; Bigner, D.D.; et al. The role of angiogenesis in Group 3 medulloblastoma pathogenesis and survival. Neuro-oncology 2017, 19, 1217-1227. [CrossRef]

116. Gholamin, S.; Mitra, S.S.; Feroze, A.H.; Liu, J.; Kahn, S.A.; Zhang, M.; Esparza, R.; Richard, C.; Ramaswamy, V.; Remke, M.; et al. Disrupting the CD47-SIRPalpha anti-phagocytic axis by a humanized anti-CD47 antibody is an efficacious treatment for malignant pediatric brain tumors. Sci. Transl. Med. 2017, 9. [CrossRef] [PubMed]

117. Northcott, P.A.; Korshunov, A.; Pfister, S.; Taylor, M. The clinical implications of medulloblastoma subgroups. Nat. Rev. Neurol. 2012, 8, 340-351. [CrossRef] 
118. Northcott, P.A.; Hielscher, T.; Dubuc, A.; Mack, S.C.; Shih, D.J.H.; Remke, M.; Al-Halabi, H.; Albrecht, S.; Jabado, N.; Eberhart, C.G.; et al. Pediatric and adult sonic hedgehog medulloblastomas are clinically and molecularly distinct. Acta Neuropathol. 2011, 122, 231-240. [CrossRef]

119. Northcott, P.A.; Shih, D.J.H.; Remke, M.; Cho, Y.-J.; Kool, M.; Hawkins, C.; Eberhart, C.G.; Dubuc, A.; Guettouche, T.; Cardentey, Y.; et al. Rapid, reliable, and reproducible molecular sub-grouping of clinical medulloblastoma samples. Acta Neuropathol. 2011, 123, 615-626. [CrossRef] [PubMed]

120. Roussel, M.F.; Robinson, G.W. Role of MYC in Medulloblastoma. Cold Spring Harb. Perspect. Med. 2013, 3, a014308. [CrossRef]

121. Huether, R.; Dong, L.; Chen, X.; Wu, G.; Parker, M.; Wei, L.; Ma, J.; Edmonson, M.N.; Hedlund, E.K.; Rusch, M.C.; et al. The landscape of somatic mutations in epigenetic regulators across 1,000 paediatric cancer genomes. Nat. Commun. 2014, 5, 3630. [CrossRef]

122. Pugh, T.J.; Weeraratne, S.D.; Archer, T.C.; Krummel, D.A.P.; Auclair, D.; Bochicchio, J.; Carneiro, M.O.; Carter, S.L.; Cibulskis, K.; Erlich, R.L.; et al. Medulloblastoma exome sequencing uncovers subtype-specific somatic mutations. Nature 2012, 488, 106-110. [CrossRef]

123. Ramaswamy, V.; Remke, M.; Adamski, J.; Bartels, U.; Tabori, U.; Wang, X.; Huang, A.; Hawkins, C.; Mabbott, D.; Laperriere, N.; et al. Medulloblastoma subgroup-specific outcomes in irradiated children: Who are the true high-risk patients? Neuro-oncology 2016, 18, 291-297. [CrossRef]

124. Forget, A.; Martignetti, L.; Puget, S.; Calzone, L.; Brabetz, S.; Picard, D.; Montagud, A.; Liva, S.; Sta, A.; Dingli, F.; et al. Aberrant ERBB4-SRC Signaling as a Hallmark of Group 4 Medulloblastoma Revealed by Integrative Phosphoproteomic Profiling. Cancer Cell 2018, 34, 379-395.e7. [CrossRef]

125. Archer, T.C.; Ehrenberger, T.; Mundt, F.; Gold, M.P.; Krug, K.; Mah, C.K.; Mahoney, E.L.; Daniel, C.J.; LeNail, A.; Ramamoorthy, D.; et al. Proteomics, Post-translational Modifications, and Integrative Analyses Reveal Molecular Heterogeneity within Medulloblastoma Subgroups. Cancer Cell 2018, 34, 396-410.e8. [CrossRef]

126. Esteller, M. Epigenetics in cancer. N. Engl. J. Med. 2008, 358, 1148-1159. [CrossRef]

127. Dubuc, A.M.; Remke, M.; Korshunov, A.; Northcott, P.A.; Zhan, S.H.; Mendez-Lago, M.; Kool, M.; Jones, D.T.W.; Unterberger, A.; Morrissy, A.S.; et al. Aberrant patterns of H3K4 and H3K27 histone lysine methylation occur across subgroups in medulloblastoma. Acta Neuropathol. 2012, 125, 373-384. [CrossRef] [PubMed]

128. Cao, R.; Wang, L.; Wang, H.; Xia, L.; Erdjument-Bromage, H.; Tempst, P.; Jones, R.S.; Zhang, Y. Role of Histone H3 Lysine 27 Methylation in Polycomb-Group Silencing. Science 2002, 298, 1039-1043. [CrossRef] [PubMed]

129. Vo, B.T.; Li, C.; Morgan, M.A.; Theurillat, I.; Finkelstein, D.; Wright, S.; Hyle, J.; Smith, S.M.; Fan, Y.; Wang, Y.-D.; et al. Inactivation of Ezh2 Upregulates Gfi1 and Drives Aggressive Myc-Driven Group 3 Medulloblastoma. Cell Rep. 2017, 18, 2907-2917. [CrossRef] [PubMed]

130. Kim, K.H.; Roberts, C.W. Targeting EZH2 in cancer. Nat. Med. 2016, 22, 128-134. [CrossRef]

131. Furlan, A.; Agbazahou, F.; Henry, M.; Gonzalez-Pisfil, M.; Le Nézet, C.; Champelovier, D.; Fournier, M.; Vandenbunder, B.; Bidaux, G.; Héliot, L. P-TEFb and Brd4: Actors of the transcription pause release as therapeutical targets. Med. Sci. 2018, 34, 685-692.

132. Song, H.; Bhakat, R.; Kling, M.J.; Coulter, D.W.; Chaturvedi, N.K.; Ray, S.; Joshi, S.S. Targeting cyclin-dependent kinase 9 sensitizes medulloblastoma cells to chemotherapy. Biochem. Biophys. Res. Commun. 2019, 520, 250-256. [CrossRef]

133. Shi, J.; Vakoc, C.R. The Mechanisms behind the Therapeutic Activity of BET Bromodomain Inhibition. Mol. Cell 2014, 54, 728-736. [CrossRef] [PubMed]

134. Henssen, A.; Thor, T.; Odersky, A.; Heukamp, L.; El-Hindy, N.; Beckers, A.; Slpeleman, F.; Althoff, K.; Schäfers, S.; Schramm, A.; et al. BET bromodomain protein inhibition is a therapeutic option for medulloblastoma. Oncotarget 2013, 4, 2080-2095. [CrossRef]

135. Parsons, D.W.; Li, M.; Zhang, X.; Jones, S.; Leary, R.J.; Lin, J.C.-H.; Boca, S.M.; Carter, H.; Samayoa, J.; Bettegowda, C.; et al. The Genetic Landscape of the Childhood Cancer Medulloblastoma. Science 2011, 331, 435-439. [CrossRef] [PubMed]

136. Wilson, B.G.; Wang, X.; Shen, X.; McKenna, E.S.; Lemieux, M.; Cho, Y.-J.; Koellhoffer, E.; Pomeroy, S.L.; Orkin, S.H.; Roberts, C.W. Epigenetic Antagonism between Polycomb and SWI/SNF Complexes during Oncogenic Transformation. Cancer Cell 2010, 18, 316-328. [CrossRef]

137. Leung, W.C.; Makharashvili, N.; Agarwal, P.; Chiu, L.-Y.; Pourpre, R.; Cammarata, M.B.; Cannon, J.R.; Sherker, A.; Durocher, D.; Brodbelt, J.S.; et al. ZMYM3 regulates BRCA1 localization at damaged chromatin to promote DNA repair. Genes Dev. 2017, 31, 260-274. [CrossRef]

138. Kodan, A.; Futamata, R.; Kimura, Y.; Kioka, N.; Nakatsu, T.; Kato, H.; Ueda, K. ABCB1/MDR1/P-gp employs an ATP-dependent twist-and-squeeze mechanism to export hydrophobic drugs. FEBS Lett. 2021, 595, 707-716. [CrossRef] [PubMed]

139. Kara, A.; Özgür, A.; Nalbantoğlu, S.; Karadağ, A. DNA repair pathways and their roles in drug resistance for lung adenocarcinoma. Mol. Biol. Rep. 2021, 48, 3813-3825. [CrossRef]

140. Bobola, M.S.; Finn, L.S.; Ellenbogen, R.G.; Geyer, J.R.; Berger, M.S.; Braga, J.M.; Meade, E.H.; Gross, M.E.; Silber, J.R. Apurinic/Apyrimidinic Endonuclease Activity Is Associated with Response to Radiation and Chemotherapy in Medulloblastoma and Primitive Neuroectodermal Tumors. Clin. Cancer Res. 2005, 11, 7405-7414. [CrossRef] [PubMed]

141. Kievit, F.M.; Stephen, Z.R.; Wang, K.; Dayringer, C.J.; Sham, J.G.; Ellenbogen, R.G.; Silber, J.R.; Zhang, M. Nanoparticle mediated silencing of DNA repair sensitizes pediatric brain tumor cells to gamma-irradiation. Mol. Oncol. 2015, 9, 1071-1080. [CrossRef] 
142. Song, H.; Xi, S.; Chen, Y.; Pramanik, S.; Zeng, J.; Roychoudhury, S.; Harris, H.; Akbar, A.; Elhag, S.S.; Coulter, D.W.; et al. Histone chaperone FACT complex inhibitor CBL0137 interferes with DNA damage repair and enhances sensitivity of medulloblastoma to chemotherapy and radiation. Cancer Lett. 2021, 520, 201-212. [CrossRef] [PubMed]

143. Wang, J.; Sui, Y.; Li, Q.; Zhao, Y.; Dong, X.; Yang, J.; Liang, Z.; Han, Y.; Tang, Y.; Ma, J. Effective inhibition of MYC-amplified group 3 medulloblastoma by FACT-targeted curaxin drug CBL0137. Cell Death Dis. 2020, 11, 1029. [CrossRef] [PubMed]

144. De, S.; Lindner, D.J.; Coleman, C.J.; Wildey, G.; Dowlati, A.; Stark, G.R. The FACT inhibitor CBL0137 Synergizes with Cisplatin in Small-Cell Lung Cancer by Increasing NOTCH1 Expression and Targeting Tumor-Initiating Cells. Cancer Res. 2018, 78, $2396-2406$. [CrossRef]

145. Dermawan, J.K.T.; Hitomi, M.; Silver, D.J.; Wu, Q.; Sandlesh, P.; Sloan, A.E.; Purmal, A.A.; Gurova, K.V.; Rich, J.N.; Lathia, J.D.; et al. Pharmacological Targeting of the Histone Chaperone Complex FACT Preferentially Eliminates Glioblastoma Stem Cells and Prolongs Survival in Preclinical Models. Cancer Res. 2016, 76, 2432-2442. [CrossRef]

146. Frock, R.L.; Sadeghi, C.; Meng, J.; Wang, J.L. DNA End Joining: G0-ing to the Core. Biomolecules 2021, 11, 1487. [CrossRef] [PubMed]

147. Elbakry, A.; Lobrich, M. Homologous Recombination Subpathways: A Tangle to Resolve. Front. Genet. 2021, $12,723847$. [CrossRef] [PubMed]

148. Chen, Y.; Li, Y.; Xiong, J.; Lan, B.; Wang, X.; Liu, J.; Lin, J.; Fei, Z.; Zheng, X.; Chen, C. Role of PRKDC in cancer initiation, progression, and treatment. Cancer Cell Int. 2021, 21, 563. [CrossRef]

149. Hwang, J.W.; Kim, S.-N.; Myung, N.; Song, D.; Han, G.; Bae, G.-U.; Bedford, M.T.; Kim, Y.K. PRMT5 promotes DNA repair through methylation of 53BP1 and is regulated by Src-mediated phosphorylation. Commun. Biol. 2020, 3, 428. [CrossRef]

150. Clarke, T.L.; Sanchez-Bailon, M.P.; Chiang, K.; Reynolds, J.J.; Ruiz, J.H.; Bandeiras, T.; Matias, P.; Maslen, S.L.; Skehel, J.M.; Stewart, G.; et al. PRMT5-Dependent Methylation of the TIP60 Coactivator RUVBL1 Is a Key Regulator of Homologous Recombination. Mol. Cell 2017, 65, 900-916.e7. [CrossRef]

151. Chaturvedi, N.K.; Mahapatra, S.; Kesherwani, V.; Kling, M.J.; Shukla, M.; Ray, S.; Kanchan, R.; Perumal, N.; McGuire, T.R.; Sharp, J.G.; et al. Role of protein arginine methyltransferase 5 in group 3 (MYC-driven) Medulloblastoma. BMC Cancer 2019, $19,1056$. [CrossRef]

152. Owens, J.L.; Beketova, E.; Liu, S.; Tinsley, S.L.; Asberry, A.M.; Deng, X.; Huang, J.; Li, C.; Wan, J.; Hu, C.-D. PRMT5 Cooperates with pICln to Function as a Master Epigenetic Activator of DNA Double-Strand Break Repair Genes. iScience 2019, 23, 100750. [CrossRef] [PubMed]

153. ENCODE Project Consortium. An integrated encyclopedia of DNA elements in the human genome. Nature 2012, 489, 57-74. [CrossRef] [PubMed]

154. Nie, L.; Wu, H.-J.; Hsu, J.-M.; Chang, S.-S.; Labaff, A.M.; Li, C.-W.; Wang, Y.; Hsu, J.L.; Hung, M.-C. Long non-coding RNAs: Versatile master regulators of gene expression and crucial players in cancer. Am. J. Transl. Res. 2012, 4, 127-150. [PubMed]

155. Joshi, P.; Katsushima, K.; Zhou, R.; Meoded, A.; Stapleton, S.; Jallo, G.; Raabe, E.; Eberhart, C.G.; Perera, R.J. The therapeutic and diagnostic potential of regulatory noncoding RNAs in medulloblastoma. Neuro-oncol. Adv. 2019, 1. [CrossRef] [PubMed]

156. Bartel, D.P. MicroRNAs: Genomics, biogenesis, mechanism, and function. Cell 2004, 116, 281-297. [CrossRef]

157. Ameres, S.L.; Zamore, P. Diversifying microRNA sequence and function. Nat. Rev. Mol. Cell Biol. 2013, 14, 475-488. [CrossRef] [PubMed]

158. Ferretti, E.; De Smaele, E.; Miele, E.; Laneve, P.; Po, A.; Pelloni, M.; Paganelli, A.; Di Marcotullio, L.; Caffarelli, E.; Screpanti, I.; et al. Concerted microRNA control of Hedgehog signalling in cerebellar neuronal progenitor and tumour cells. EMBO J. 2008, 27, 2616-2627. [CrossRef]

159. Ferretti, E.; De Smaele, E.; Po, A.; Di Marcotullio, L.; Tosi, E.; Espinola, M.S.B.; Di Rocco, C.; Riccardi, R.; Giangaspero, F.; Farcomeni, A.; et al. MicroRNA profiling in human medulloblastoma. Int. J. Cancer 2008, 124, 568-577. [CrossRef]

160. Grunder, E.; D'Ambrosio, R.; Fiaschetti, G.; Abela, L.; Arcaro, A.; Zuzak, T.; Ohgaki, H.; Lv, S.-Q.; Shalaby, T.; Grotzer, M. MicroRNA-21 suppression impedes medulloblastoma cell migration. Eur. J. Cancer 2011, 47, 2479-2490. [CrossRef]

161. Ray, S.; Coulter, D.W.; Gray, S.D.; Sughroue, J.A.; Roychoudhury, S.; McIntyre, E.M.; Chaturvedi, N.K.; Bhakat, K.K.; Joshi, S.S.; McGuire, T.R.; et al. Suppression of STAT3 NH2-terminal domain chemosensitizes medulloblastoma cells by activation of protein inhibitor of activated STAT3 via de-repression by microRNA-21. Mol. Carcinog. 2018, 57, 536-548. [CrossRef] [PubMed]

162. Shirsat, N.V.; Gokhale, A.; Kunder, R.; Goel, A.; Sarin, R.; Moiyadi, A.; Shenoy, A.; Mamidipally, C.; Noronha, S.; Kannan, S. Distinctive microRNA signature of medulloblastomas associated with the WNT signaling pathway. J. Cancer Res. Ther. 2010, 6, 521-529. [CrossRef]

163. Kunder, R.; Jalali, R.; Sridhar, E.; Moiyadi, A.; Goel, N.; Goel, A.; Gupta, T.; Krishnatry, R.; Kannan, S.; Kurkure, P.; et al. Real-time PCR assay based on the differential expression of microRNAs and protein-coding genes for molecular classification of formalin-fixed paraffin embedded medulloblastomas. Neuro-oncology 2013, 15, 1644-1651. [CrossRef]

164. Northcott, P.A.; Fernandez-L, A.; Hagan, J.P.; Ellison, D.W.; Grajkowska, W.; Gillespie, Y.; Grundy, R.; Van Meter, T.; Rutka, J.T.; Croce, C.M.; et al. The miR-17/92 polycistron is up-regulated in sonic hedgehog-driven medulloblastomas and induced by $\mathrm{N}$-myc in sonic hedgehog-treated cerebellar neural precursors. Cancer Res. 2009, 69, 3249-3255. [CrossRef]

165. Gershanov, S.; Toledano, H.; Michowiz, S.; Barinfeld, O.; Pinhasov, A.; Goldenberg-Cohen, N.; Salmon-Divon, M. MicroRNAmRNA expression profiles associated with medulloblastoma subgroup 4. Cancer Manag. Res. 2018, 10, 339-352. [CrossRef] 
166. McDonald, J.D.; Daneshvar, L.; Willert, J.R.; Matsumura, K.; Waldman, F.; Cogen, P.H. Physical mapping of chromosome 17p13.3 in the region of a putative tumor suppressor gene important in medulloblastoma. Genomics 1994, 23, 229-232. [CrossRef] [PubMed]

167. Pietsch, T.; Koch, A.; Wiestler, O.D. Molecular genetic studies in medulloblastomas: Evidence for tumor suppressor genes at the chromosomal regions 1q31-32 and 17p13. Klin. Padiatr. 1997, 209, 150-155. [CrossRef]

168. Cogen, P.H.; McDonald, J.D. Tumor suppressor genes and medulloblastoma. J. Neuro-oncol. 1996, 29, 103-112. [CrossRef] [PubMed]

169. Cvekl, A.; Zavadil, J.; Birshtein, B.K.; Grotzer, M. Analysis of transcripts from 17p13.3 in medulloblastoma suggests ROX/MNT as a potential tumour suppressor gene. Eur. J. Cancer 2004, 40, 2525-2532. [CrossRef] [PubMed]

170. Hoff, C.; Seranski, P.; Mollenhauer, J.; Korn, B.; Detzel, T.; Reinhardt, R.; Ramser, J.; Poustka, A. Physical and Transcriptional Mapping of the 17p13.3 Region That Is Frequently Deleted in Human Cancer. Genomics 2000, 70, 26-33. [CrossRef] [PubMed]

171. Briggs, K.J.; Corcoran-Schwartz, I.M.; Zhang, W.; Harcke, T.; Devereux, W.L.; Baylin, S.B.; Eberhart, C.G.; Watkins, D.N Cooperation between the Hic1 and Ptch1 tumor suppressors in medulloblastoma. Genes Dev. 2008, 22, 770-785. [CrossRef] [PubMed]

172. Kanchan, R.K.; Perumal, N.; Atri, P.; Chirravuri Venkata, R.; Thapa, I.; Klinkebiel, D.L.; Donson, A.M.; Perry, D.; Punsoni, M.; Talmon, G.A.; et al. MiR-1253 exerts tumor-suppressive effects in medulloblastoma via inhibition of CDK6 and CD276 (B7-H3). Brain Pathol. 2020, 30, 732-745. [CrossRef]

173. Xu, Q.F.; Pan, Y.W.; Li, L.C.; Zhou, Z.; Huang, Q.L.; Pang, J.C.; Zhu, X.P.; Ren, Y.; Yang, H.; Ohgaki, H.; et al. MiR-22 is frequently downregulated in medulloblastomas and inhibits cell proliferation via the novel target PAPST1. Brain Pathol. 2014, 24, 568-583. [CrossRef] [PubMed]

174. Perumal, N.; Kanchan, R.K.; Doss, D.; Bastola, N.; Atri, P.; Chirravuri-Venkata, R.; Thapa, I.; Vengoji, R.; Maurya, S.K.; Klinkebiel, D.; et al. MiR-212-3p functions as a tumor suppressor gene in group 3 medulloblastoma via targeting nuclear factor I/B (NFIB). Acta Neuropathol. Commun. 2021, 9, 1-19. [CrossRef] [PubMed]

175. Liu, S.; Liang, J.; Liu, Z.; Zhang, C.; Wang, Y.; Watson, A.H.; Zhou, C.; Zhang, F.; Wu, K.; Zhang, F.; et al. The Role of CD276 in Cancers. Front. Oncol. 2021, 11. [CrossRef]

176. Quinn, J.J.; Chang, H.Y. Unique features of long non-coding RNA biogenesis and function. Nat. Rev. Genet. 2016, 17, 47-62. [CrossRef]

177. Schmitt, A.M.; Chang, H.Y. Long Noncoding RNAs in Cancer Pathways. Cancer Cell 2016, 29, 452-463. [CrossRef]

178. Li, B.; Shen, M.; Yao, H.; Chen, X.; Xiao, Z. Long Noncoding RNA TP73-AS1 Modulates Medulloblastoma Progression In Vitro And In Vivo By Sponging miR-494-3p And Targeting EIF5A2. OncoTargets Ther. 2019, 12, 9873-9885. [CrossRef]

179. Zhang, Y.; Wang, T.; Wang, S.; Xiong, Y.; Zhang, R.; Zhang, X.; Zhao, J.; Yang, A.-G.; Wang, L.; Jia, L. Nkx2-2as Suppression Contributes to the Pathogenesis of Sonic Hedgehog Medulloblastoma. Cancer Res. 2017, 78, 962-973. [CrossRef]

180. Katsushima, K.; Lee, B.; Kunhiraman, H.; Zhong, C.; Murad, R.; Yin, J.; Liu, B.; Garancher, A.; Gonzalez-Gomez, I.; Monforte, H.L.; et al. The long noncoding RNA lnc-HLX-2-7 is oncogenic in Group 3 medulloblastomas. Neuro-oncology 2020, 23, 572-585. [CrossRef]

181. Laneve, P.; Po, A.; Favia, A.; Legnini, I.; Alfano, V.; Rea, J.; Di Carlo, V.; Bevilacqua, V.; Miele, E.; Mastronuzzi, A.; et al. The long noncoding RNA linc-NeD125 controls the expression of medulloblastoma driver genes by microRNA sponge activity. Oncotarget 2017, 8, 31003-31015. [CrossRef] [PubMed]

182. Mutlu, M.; Tekin, C.; Aksoy, S.A.; Taskapilioglu, M.O.; Kaya, S.; Balcin, R.N.; Ocak, P.E.; Kocaeli, H.; Bekar, A.; Tolunay, S.; et al. Long non-coding RNAs as a predictive markers of group 3 medulloblastomas. Neurol. Res. 2021. [CrossRef] [PubMed]

183. Kesherwani, V.; Shukla, M.; Coulter, D.W.; Sharp, J.G.; Joshi, S.S.; Chaturvedi, N.K. Long non-coding RNA profiling of pediatric Medulloblastoma. BMC Med. Genom. 2020, 13, 87. [CrossRef]

184. Yu, C.-Y.; Kuo, H.-C. The emerging roles and functions of circular RNAs and their generation. J. Biomed. Sci. 2019, 26, 29. [CrossRef] [PubMed]

185. Lv, T.; Miao, Y.F.; Jin, K.; Han, S.; Xu, T.Q.; Qiu, Z.L.; Zhang, X.H. Dysregulated circular RNAs in medulloblastoma regulate proliferation and growth of tumor cells via host genes. Cancer Med. 2018, 7, 6147-6157. [CrossRef] 